\title{
Modeling of HCHO and CHOCHO at a semi-rural site in southern China during the PRIDE-PRD2006 campaign
}

\author{
X. Li ${ }^{1,2}$, F. Rohrer ${ }^{1}$, T. Brauers ${ }^{1, \dagger}$, A. Hofzumahaus ${ }^{1}$, K. Lu ${ }^{1, *}$, M. Shao ${ }^{2}$, Y. H. Zhang ${ }^{2}$, and A. Wahner ${ }^{1}$ \\ ${ }^{1}$ Institut für Energie- und Klimaforschung Troposphäre (IEK-8), Forschungszentrum Jülich, Jülich, Germany \\ ${ }^{2}$ College of Environmental Sciences and Engineering, Peking University, Beijing, China \\ $\dagger$ deceased \\ *now at: College of Environmental Sciences and Engineering, Peking University, Beijing, China
}

Correspondence to: X. Li (x.li@fz-juelich.de) and A. Wahner (a.wahner@fz-juelich.de)

Received: 4 December 2013 - Published in Atmos. Chem. Phys. Discuss.: 17 December 2013

Revised: 25 September 2014 - Accepted: 19 October 2014 - Published: 21 November 2014

\begin{abstract}
HCHO}$ and $\mathrm{CHOCHO}$ are important trace gases in the atmosphere, serving as tracers of VOC oxidations. In the past decade, high concentrations of $\mathrm{HCHO}$ and $\mathrm{CHOCHO}$ have been observed for the Pearl River Delta (PRD) region in southern China. In this study, we performed box model simulations of $\mathrm{HCHO}$ and $\mathrm{CHOCHO}$ at a semi-rural site in the PRD, focusing on understanding their sources and sinks and factors influencing the $\mathrm{CHOCHO}$ to $\mathrm{HCHO}$ ratio $\left(R_{\mathrm{GF}}\right)$. The model was constrained by the simultaneous measurements of trace gases and radicals. Isoprene oxidation by $\mathrm{OH}$ radicals is the major pathway forming $\mathrm{HCHO}$, followed by degradations of alkenes, aromatics, and alkanes. The production of $\mathrm{CHOCHO}$ is dominated by isoprene and aromatic degradation; contributions from other NMHCs are of minor importance. Compared to the measurement results, the model predicts significant higher $\mathrm{HCHO}$ and $\mathrm{CHOCHO}$ concentrations. Sensitivity studies suggest that fresh emissions of precursor VOCs, uptake of $\mathrm{HCHO}$ and $\mathrm{CHOCHO}$ by aerosols, fast vertical transport, and uncertainties in the treatment of dry deposition all have the potential to contribute significantly to this discrepancy. Our study indicates that, in addition to chemical considerations (i.e., VOC composition, $\mathrm{OH}$ and $\mathrm{NO}_{\mathrm{x}}$ levels), atmospheric physical processes (e.g., transport, dilution, deposition) make it difficult to use the $\mathrm{CHOCHO}$ to $\mathrm{HCHO}$ ratio as an indicator for the origin of air mass composition.
\end{abstract}

\section{Introduction}

The degradation of directly emitted volatile organic compounds (VOCs) results in the formation of ozone $\left(\mathrm{O}_{3}\right)$ and secondary organic aerosols (SOAs) in the troposphere (Finlayson-Pitts and Pitts, 2000). This process consists of the oxidation of VOCs by hydroxyl radical $(\mathrm{OH}), \mathrm{O}_{3}$, and nitrate radical $\left(\mathrm{NO}_{3}\right)$. Detailed understanding of the VOCs' degradation mechanism is challenged by the co-existence of vast variety of VOC species in the atmosphere. However, investigations on ubiquitous oxidation intermediates, e.g., formaldehyde (HCHO) and glyoxal (CHOCHO), can help us to test and improve the current knowledge of the VOCs' sources and degradation pathways.

$\mathrm{HCHO}$ is the most abundant carbonyl compound in the atmosphere. Maximum HCHO concentrations can reach $100 \mathrm{ppb}$ in polluted areas whereas sub-ppb levels are found in remote areas (Finlayson-Pitts and Pitts, 2000). Most of $\mathrm{HCHO}$ is produced during the oxidation of organic compounds (Fortems-Cheiney et al., 2012). While methane $\left(\mathrm{CH}_{4}\right)$ oxidation by $\mathrm{OH}$ radicals is the major source of $\mathrm{HCHO}$ in remote areas, the $\mathrm{HCHO}$ production in regions (e.g., forest, urban area) with elevated non-methane hydrocarbons (NMHCs) (i.e., alkanes, alkenes, aromatics, isoprene, and terpenes) is dominated by their degradation. $\mathrm{Di}$ rect emissions of $\mathrm{HCHO}$ originate mainly from fossil fuel combustion (Schauer et al., 1999, 2002), biomass burning (Lee et al., 1997), and vegetation (DiGangi et al., 2011), but are usually of minor importance (Parrish et al., 2012). The known removal pathways of $\mathrm{HCHO}$ in the atmosphere are 
reaction with $\mathrm{OH}$, photolysis, and dry / wet deposition. Heterogeneous uptake by cloud droplets and aerosols is speculated to be an additional sink of HCHO, which could contribute to the HCHO destruction (Zhou et al., 1996; Tie et al., 2001; Fried et al., 2003a). However, the existence of this process in the lower troposphere is still under discussion. Laboratory experiments indicate reactive loss of $\mathrm{HCHO}$ can happen on surfaces of $\mathrm{H}_{2} \mathrm{SO}_{4}$ aerosols (Jayne et al., 1996), mineral dust aerosols (Sassine et al., 2010), and organic aerosols (Li et al., 2011). Field observations by Wang et al. (2010) suggest an uptake of $\mathrm{HCHO}$ by aerosols in the presence of amines (or ammonia) and carbonyl compounds. $\mathrm{HCHO}$ oligomerization is also proposed to contribute to the partitioning of gaseous $\mathrm{HCHO}$ to aerosol phase (Toda et al., 2014). But, during a chamber study, Kroll et al. (2005) did not find any growth of both neutral $\left(\left(\mathrm{NH}_{4}\right)_{2} \mathrm{SO}_{4}\right)$ and acidic $\left(\mathrm{NH}_{4} \mathrm{HSO}_{4}\right)$ aerosols in the presence of gaseous $\mathrm{HCHO}$, suggesting that the uptake of $\mathrm{HCHO}$ by aerosols is unlikely taking place. Although numerical simulations of $\mathrm{HCHO}$, either by multi-dimensional models or box models, can in some cases reproduce HCHO observations (Wagner et al., 2001; Fried et al., 2003b; MacDonald et al., 2012), significant discrepancies between modeled and measured HCHO concentration have been frequently found (Choi et al., 2010; Fried et al., 2011, and references therein). The model underestimation can arise from the following: deviation from the steadystate assumption (Fried et al., 2003a), direct emissions and their transport (Fried et al., 2011), missing consideration of $\mathrm{HCHO}$ production from unmeasured precursors (Kormann et al., 2003; Choi et al., 2010), etc. If the steady-state assumption is disturbed, e.g., in the vicinity of fresh emissions, the model can also overpredict the measured HCHO concentration (Fried et al., 2011).

$\mathrm{CHOCHO}$ is the smallest dicarbonyl compound in the atmosphere. Ambient concentration of $\mathrm{CHOCHO}$ ranges from tens of ppt in remote and rural areas to $\approx 1 \mathrm{ppb}$ in heavy polluted urban regions (e.g., Volkamer et al., 2007; Washenfelder et al., 2011; DiGangi et al., 2012). Compared to $\mathrm{HCHO}, \mathrm{CHOCHO}$ has nearly no primary sources except biomass burning and biofuel combustion. Globally, isoprene and ethyne are the major precursors of $\mathrm{CHOCHO}$ (Fu et al., 2008). While local CHOCHO production is dominated by aromatics degradation in urban or sub-urban areas (Volkamer et al., 2007; Washenfelder et al., 2011), significant contributions from 2-methyl-3-buten-2-ol (MBO) and isoprene oxidation are identified for rural areas (Huisman et al., 2011). Removal of gaseous CHOCHO is driven by reaction with $\mathrm{OH}$, photolysis, deposition, and loss on aerosol surfaces (Fu et al., 2008). By comparing CHOCHO column densities derived from a global model simulation to satellite observations, Myriokefalitakis et al. (2008) and Stavrakou et al. (2009) speculate of a missing global source of CHOCHO. Similar study performed recently by Liu et al. (2012) suggests that the missing CHOCHO sources in China is most likely due to the underestimation of aromatics in the VOC emission inventory. As first indicated by Volkamer et al. (2007), if loss of CHOCHO on aerosol surfaces is not taken into account, models can substantially overestimate measured CHOCHO concentrations. Laboratory studies found that uptake of CHOCHO by aerosols is mainly through polymerization process and is related with the acidity and the ionic strength within the aqueous phase of aerosols (Jang and Kamens, 2001; Liggio et al., 2005; Kroll et al., 2005). Once $\mathrm{CHOCHO}$ is taken up by aerosols, it can contribute to the formation of secondary organic aerosols (Volkamer et al., 2007; Tan et al., 2009; Washenfelder et al., 2011).

Given that $\mathrm{HCHO}$ and $\mathrm{CHOCHO}$ have similar sinks but different sources, the $\mathrm{CHOCHO}$ to $\mathrm{HCHO}$ ratio $\left(R_{\mathrm{GF}}\right)$ has been proposed to be a tracer of changes of VOC mixture in the atmosphere. Based on satellite observations, Vrekoussis et al. (2010) conclude that regions with $R_{\mathrm{GF}}$ lower than 0.045 are under influence of anthropogenic emissions, whereas $R_{\mathrm{GF}}$ higher than 0.045 often indicates that VOC emissions mostly originate from biogenic sources. Average $R_{\mathrm{GF}}$ up to $0.2-0.4$ were observed by MacDonald et al. (2012) in an Asian tropic forest. However, after analyzing the measured $R_{\mathrm{GF}}$ and relevant trace gases at a rural site, DiGangi et al. (2012) found that higher $R_{\mathrm{GF}}$ corresponded to increased anthropogenic impact on local photochemistry.

The Pearl River Delta (PRD) region located in southern China has been identified by satellite observations as the region with high levels of $\mathrm{HCHO}$ and $\mathrm{CHOCHO}$ (Wittrock et al., 2006; Vrekoussis et al., 2010). Yet simultaneous ground-based measurements of HCHO and CHOCHO in this region are quite limited. During the PRIDE-PRD2006 campaign, which was dedicated to the understanding of the formation mechanism of $\mathrm{O}_{3}$ and SOA in this heavy polluted region, we performed 1 month of continuous MAXDOAS observations for $\mathrm{HCHO}$ and $\mathrm{CHOCHO}$ at a semirural site in the PRD (Li et al., 2013). The measured HCHO and $\mathrm{CHOCHO}$ concentrations as well as $R_{\mathrm{GF}}$ were as high as those obtained in other urban environments. Simultaneous measurements of $\mathrm{HO}_{\mathrm{X}}\left(=\mathrm{OH}+\mathrm{HO}_{2}\right)$ radicals, trace gases, and aerosols suggest highly active photochemistry under the influence of both anthropogenic and biogenic emissions (Lou et al., 2010; Hu et al., 2012; Lu et al., 2012). In this paper, we will focus on investigating the production and destruction pathways of $\mathrm{HCHO}$ and CHOCHO during the PRIDEPRD2006 campaign, and try to understand the change of $R_{\mathrm{GF}}$ with the change of air mass compositions.

\section{Approach}

\subsection{Field measurements}

The PRIDE-PRD2006 field campaign took place in July 2006 in the Pearl River Delta (PRD) region in southern China within the framework of the "Program of Regional Integrated Experiments of Air Quality over the Pearl River 
Delta" (PRIDE-PRD2006). Field measurements of $\mathrm{HO}_{\mathrm{X}}$ radicals, trace gases, aerosols, and meteorological parameters were performed at a semi-rural site called "Back Garden" $\left(\mathrm{BG}, 23.50^{\circ} \mathrm{N}, 113.03^{\circ} \mathrm{E}\right)$, which is located at the northern edge of PRD. While big cities (i.e., Zhaoqing, Foshan, Guangzhou, and Dongguan) are located tens of kilometers south of the BG site, to the north of the BG site are small towns close to mountain areas. These mountain areas are typically covered by evergreen broad-leaf forest. The BG site is next to a water reservoir and is surrounded by farmland (peanuts, lychees, trees, small forests).

Concentrations of $\mathrm{HCHO}$ and $\mathrm{CHOCHO}$ were retrieved from MAX-DOAS scattered sunlight measurements at six elevation angles. Since the concentration retrieval has been described in detail in Li et al. (2013), only a brief outline follows. During the retrieval, $\mathrm{HCHO}$ and $\mathrm{CHOCHO}$ are assumed to be well-mixed in a layer with height $H$. The vertical column density (VCD) and $H$ are retrieved by comparing measured differential slant column densities (DSCDs) to those simulated by a radiative transfer model (RTM). Using the retrieved VCDs and $H$, mean mixing ratios of $\mathrm{HCHO}$ and $\mathrm{CHOCHO}$ in the well-mixed layer were calculated. In order to exclude the influence of clouds on the concentration retrieval, we only consider observations during cloudfree days. The errors of the retrieved $\mathrm{HCHO}$ and $\mathrm{CHOCHO}$ mixing ratios consist of statistical errors which arise mainly from the uncertainty of the measured DSCDs, and systematic errors which originate from the uncertainty of the RTM input parameters (e.g., aerosol optical depth, aerosol single scattering albedo, aerosol asymmetry factor under the HenyeyGreenstein approximation) and of the DSCD simulation. The systematic error is estimated to be around $35 \%$.

The MAX-DOAS measurements were performed in parallel with ground-based in situ measurements of $\mathrm{CO}, \mathrm{CH}_{4}, \mathrm{C} 3-$ $\mathrm{C} 12$ NMHCs, $\mathrm{NO}_{\mathrm{x}}\left(=\mathrm{NO}+\mathrm{NO}_{2}\right), \mathrm{O}_{3}$, aerosol physical and chemical properties, photolysis frequencies, relative humidity, and pressure on top of a hotel building (10 m a.g.1.). Simultaneously, measurements of HOx radicals, HONO, temperature, and 3d-wind were performed on top of two stacked sea containers around $20 \mathrm{~m}$ away from the hotel building. Details of these measurements were described in separate papers (Lu et al., 2012, and references therein). Instrumentation, time resolution, and accuracy for parameters used in this study are listed in Supplement Table S1.

\subsection{Model description}

Concentrations of $\mathrm{HCHO}$ and $\mathrm{CHOCHO}$ were calculated by a zero-dimensional box model using the Master Chemical Mechanism (MCM) Version 3.2 (http://mcm.leeds.ac. $\mathrm{uk} / \mathrm{MCM} /$ ). The model includes the full MCM chemistry for all measured NMHCs and their oxidation products. The model calculations were constrained to measurements of $\mathrm{OH}, \mathrm{NO}, \mathrm{NO}_{2}, \mathrm{HONO}, \mathrm{O}_{3}, \mathrm{CO}, \mathrm{CH}_{4}, \mathrm{C} 3-\mathrm{C} 12 \mathrm{NMHCs}$, photolysis frequencies, relative humidity, temperature, and pressure. Concentrations of ethane, ethene, and ethyne were fixed to $1.5 \mathrm{ppb}, 3 \mathrm{ppb}$, and $1.7 \mathrm{ppb}$, respectively, estimated from few canister samples. $\mathrm{H}_{2}$ mixing ratio was assumed to be $550 \mathrm{ppb}$. An additional loss process with a lifetime $\left(\tau_{D}\right)$ of $24 \mathrm{~h}$ was assumed for all calculated species. This lifetime corresponds to a dry deposition velocity of $1.2 \mathrm{~cm} \mathrm{~s}^{-1}$ and a well-mixed boundary layer height of about $1 \mathrm{~km}$. The model was operated in a time-dependent mode for the entire campaign period (5-25 July), with $30 \mathrm{~min}$ time resolution and a 2-day spin-up time. For periods when measured NMHCs data were not available, values were taken from the campaign mean diurnal variation. With regard to missing $\mathrm{OH}$ values, they are estimated from the measured photolysis frequency of $\mathrm{O}_{3}\left(J_{\mathrm{O} 1 \mathrm{D}}\right)$ using the empirical formula described by $\mathrm{Lu}$ et al. (2012). The model run with the above settings represents the current understanding on the $\mathrm{HCHO}$ and $\mathrm{CHOCHO}$ chemistry at the BG site, based on available precursor measurements. This base case scenario is called M0 in the text and figures. In order to investigate to which extent the model can reproduce the $\mathrm{HCHO}$ and $\mathrm{CHOCHO}$ measurements, different model scenarios were setup by including additional mechanisms in M0. Table 1 gives an overview of the employed model scenarios. In this study, we only focus on those 6 days when $\mathrm{HCHO}, \mathrm{CHOCHO}, \mathrm{NMHCs}$, and $\mathrm{OH}$ measurements were available, i.e., 12-13, 20-21, and 24-25 July.

\subsection{Model uncertainty}

The uncertainty of the model simulation of $\mathrm{HCHO}$ and $\mathrm{CHOCHO}$ can arise from the uncertainty of (1) measured trace gas concentrations, (2) measured meteorological parameters, i.e., photolysis frequencies $J$, temperature $T$, and pressure $P$, (3) reaction rate constants $k$ used in the model, and (4) the lifetime $\tau_{D}$ for dry deposition. Using the same uncertainty factors listed in Table S7 in Lu et al. (2012), we run the model base case (M0) for $n$ times ( $n$ equals to the number of parameters been considered). During each model run, the value of the considered parameter is multiplied by its uncertainty factor. The model uncertainty is estimated by error propagation from the errors of all considered parameters. Gaussian error propagation was applied within each of the first three groups. The total model errors were then calculated conservatively by linear addition of the errors from all four groups. The mean diurnal variation of the uncertainty of the modeled $\mathrm{HCHO}$ and $\mathrm{CHOCHO}$ by the model base case is shown in Fig. S2. On average, modeled HCHO and $\mathrm{CHOCHO}$ concentrations in the model base case had an uncertainty of around $55 \%$.

\section{Results}

\subsection{Measurements overview}

The entire PRIDE-PRD campaign was characterized by tropical conditions with high temperature $\left(28-36^{\circ} \mathrm{C}\right)$, high 
Table 1. Model scenarios used in the sensitivity study of HCHO and CHOCHO simulation during the PRIDE-PRD2006 campaign.

\begin{tabular}{|c|c|c|}
\hline Simulation & Mechanisms & Purpose \\
\hline M0 & MCM v3.2 with $\tau_{D}=24 \mathrm{~h}$ & Base run \\
\hline M1 & $\begin{array}{l}\text { as M0, but (1) change } \tau_{D} \text { to } 3 \mathrm{~h} \text { for the time period of } 06: 00- \\
19: 00 \text { in } 13,24 \text {, and } 25 \text { July, }(2) \text { decrease isoprene concen- } \\
\text { tration to } 52 \% \text { of the measured value for the period of } 8: 00- \\
16: 00 \text {, and (3) include measured PANs as model constraints }\end{array}$ & Influence of source terms \\
\hline M2 & $\begin{array}{l}\text { as M1, but replace } \tau_{D} \text { of } \mathrm{HCHO} \text { and } \mathrm{CHOCHO} \text { by } \tau_{\text {depo. }}= \\
v_{\text {depo. }} \cdot v_{\text {depo. }} \text { is set to } 1 \mathrm{~cm} \mathrm{~s}^{-1} \text { and } 0.3 \mathrm{~cm} \mathrm{~s}^{-1} \text { for } \mathrm{HCHO} \\
\text { and CHOCHO, respectively. }\end{array}$ & Influence of dry deposition \\
\hline M3 & $\begin{array}{l}\text { as M2, but add removal of all species by vertical dilution for } \\
\text { the period of } 06: 00-10: 00 \text {, with rate constant of } 0.41 \mathrm{~h}^{-1}\end{array}$ & Influence of vertical dilution \\
\hline M4 & $\begin{array}{l}\text { as } \mathrm{M} 3 \text {, but include uptake of } \mathrm{HCHO} \text { and } \mathrm{CHOCHO} \text { by } \\
\text { aerosols, i.e., } \frac{\mathrm{d} C}{\mathrm{~d} t}=-\frac{\gamma \times S_{\mathrm{aw}} \times v \times C^{*}}{4} \text {, with an uptake coef- } \\
\text { ficient } \gamma \text { of } 10^{-3}\end{array}$ & Influence of heterogeneous uptake \\
\hline
\end{tabular}

humidity (60-95\% RH), and high solar radiation (indicated by noontime $J_{\mathrm{NO}_{2}}$ of $(5-10) \times 10^{-3} \mathrm{~s}^{-1}$ ) (Li et al., 2012). These meteorological conditions, together with the prevailing emissions of air pollutants, are in favor of the high photochemical reactivity in the PRD region, which can be reflected by the measured high $\mathrm{OH}$ concentrations (noontime value of $\left.1.5 \times 10^{7} \mathrm{~cm}^{-3}\right)$ and HOx turnover rate $\left(3 \times 10^{8} \mathrm{~cm}^{-3} \mathrm{~s}^{-1}\right.$ around noon) (Hofzumahaus et al., 2009). For the 6 cloudfree days in this study, Fig. 1 shows the time series of measured wind speed, wind direction, $\mathrm{OH}$ reactivities of $\mathrm{C} 2-\mathrm{C} 12$ $\mathrm{NMHC}\left(k_{\mathrm{OH}}^{\mathrm{NMHC}}\right), \mathrm{OH}$ concentrations, aerosol $\left(\mathrm{PM}_{10}\right)$ surface concentrations, aerosol (PM1) compositions, and HCHO and $\mathrm{CHOCHO}$ concentrations. The wind speeds were generally below $3 \mathrm{~m} \mathrm{~s}^{-1}$. According to the wind direction, air masses arriving at the $\mathrm{BG}$ site were mainly from two directions, i.e., south on 20 and 21 July north on 13, 24, and 25 July. On 12 July, the wind was from north in the first night, and became south during daytime, and changed back to north after sunset. Peak values of $k_{\mathrm{OH}}^{\mathrm{NMHC}}$ were around $20 \mathrm{~s}^{-1}$ and normally occurred at night. Compared to southern wind days, elevated $k_{\mathrm{OH}}^{\mathrm{NMHC}}$ with average values of $5.6-6.7 \mathrm{~s}^{-1}$ were observed in the period of 09:00-18:00 in northern wind days, which was mainly attributed to the higher isoprene concentrations. This is consistent with the fact that north of BG site is close to forest areas and air masses from north are therefore influenced by biogenic emissions. However, average $\mathrm{OH}$ reactivities of anthropogenic NMHC for the same period were nearly the same in the 6 days, e.g., $k_{\mathrm{OH}}^{\mathrm{Alkene}} \approx 1.2 \mathrm{~s}^{-1}$, regardless of the origin of air masses. $\mathrm{OH}$ concentrations also do not show big difference in the 6 days, with peak values of $1.5 \times 10^{7} \mathrm{~cm}^{-3}$ around noon and values of $0-1 \times 10^{6} \mathrm{~cm}^{-3}$ during night. The aerosol (PM1) composition measurements found that almost half of the sub-micron aerosol mass consisted of organics, and the the next most found substance was sulfate. On 24 and 25 July when strong combustion events happened in the surrounding areas, the aerosol mass and surface concentrations were significantly higher than in other days. The occurrence of the combustion events can be indicated by the increase of $\mathrm{Cl}^{-}$concentration in PM1 (Hu et al., 2012). This $\mathrm{Cl}^{-}$increase is identified in the early morning of 13, 24, and 25 July and around mid-night of 25 July. Increase of $k_{\mathrm{OH}}^{\mathrm{Alkene}}$ was also observed in the combustion periods. In the 6 cloud-free days, the measured average concentrations of $\mathrm{HCHO}$ and $\mathrm{CHOCHO}$ were $7.3 \mathrm{ppb}$ and $0.37 \mathrm{ppb}$, respectively. Elevated $\mathrm{HCHO}$ and $\mathrm{CHOCHO}$ concentrations were observed during periods when combustion events were prevailing. Diurnal variability of $\mathrm{HCHO}$ and $\mathrm{CHOCHO}$ was not very prominent. After excluding the periods influenced by combustion events, a slight increase of $\mathrm{HCHO}$ concentrations can be found from early morning to 12:00, whereas $\mathrm{CHOCHO}$ concentrations are almost stable at around $0.3 \mathrm{ppb}$.

\subsection{HCHO and CHOCHO simulation by the model base case}

The simulated $\mathrm{HCHO}$ and $\mathrm{CHOCHO}$ concentrations from the model base case (M0) are shown in Fig. 2. Neither the observed diurnal variation nor the concentration can be well reproduced by the model. The model predicts HCHO maxima occurring at around 09:00 with concentrations of 30-40 ppb, followed by decrease of $\mathrm{HCHO}$ concentration to $10-25 \mathrm{ppb}$ from late morning to afternoon. In the afternoon, the simulated $\mathrm{HCHO}$ are separated into two groups; higher calculated concentrations are found when the wind is coming from the north of the BG site. This phenomenon also exists for the modeled CHOCHO. In general, the model base case overpredicts $\mathrm{HCHO}$ and $\mathrm{CHOCHO}$ concentrations by factors of 2-6. While the measurements did not find prominent diurnal variation of $\mathrm{CHOCHO} / \mathrm{HCHO}$ ratios $\left(R_{\mathrm{GF}}\right)$, the model shows 

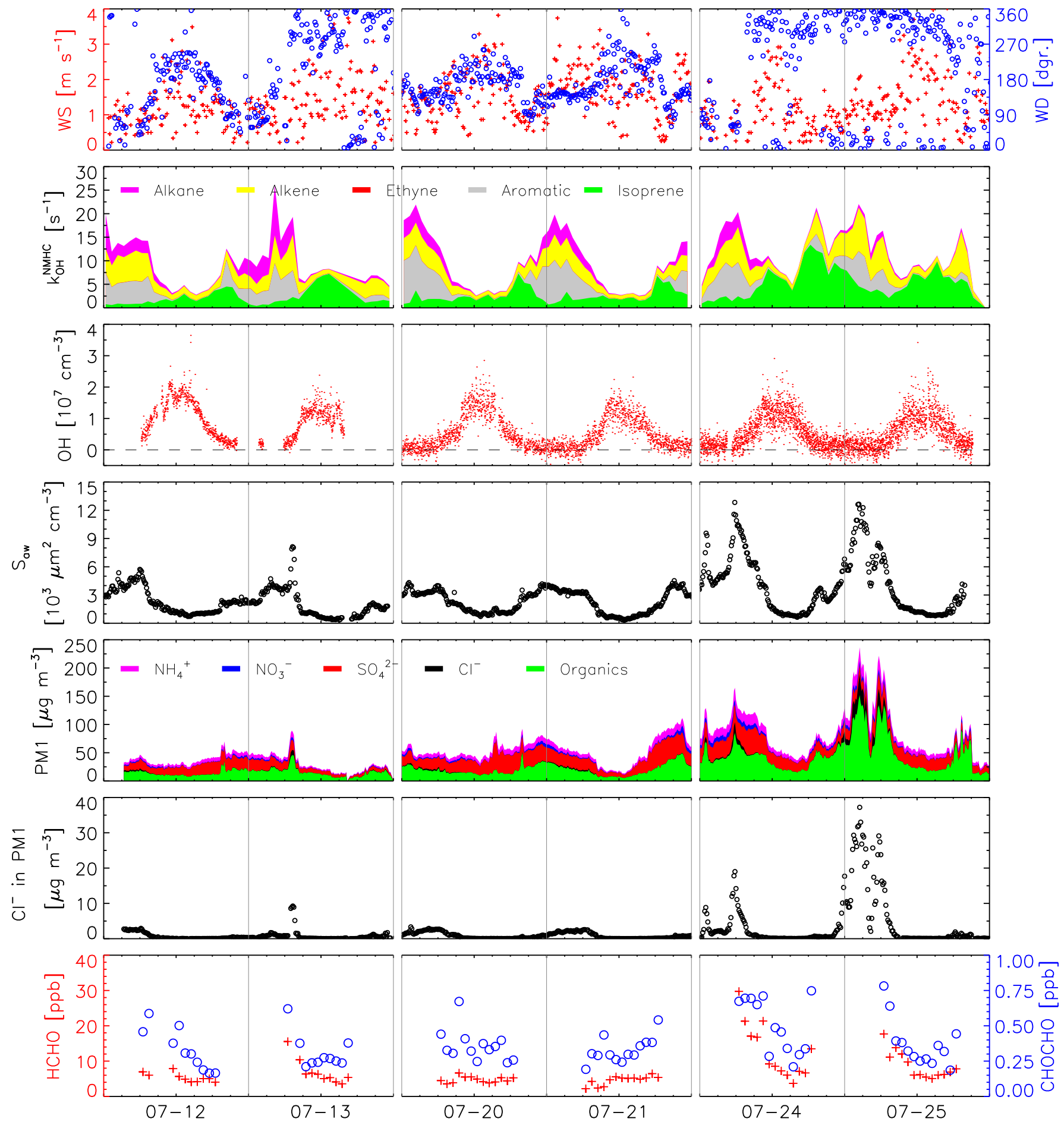

Time $[2006-M M-D D]$

Figure 1. Time series of wind speed (WS), wind direction (WD), OH reactivity of measured $\mathrm{C} 3-\mathrm{C} 12 \mathrm{NMHCs}\left(k_{\mathrm{OH}}^{\mathrm{NMHC}}\right), \mathrm{OH}$, aerosol $\left(\mathrm{PM}_{10}\right)$ surface concentration ( $S_{\mathrm{aw}}$, i.e., $S_{\mathrm{a}}$ corrected for hygroscopic growth), aerosol (PM1) compositions, HCHO, and CHOCHO for the 6 cloud-free days during the PRIDE-PRD2006 campaign. $S_{\text {aw }}$ is the RH corrected aerosol surface concentration, i.e., $S_{\mathrm{aw}}=S_{\mathrm{a}} \times f(\mathrm{RH})=$ $S_{\mathrm{a}} \times\left(1+a \times(\mathrm{RH})^{b}\right)$. The empirical factors $a$ and $b$ used to estimate $f(\mathrm{RH})$ were set to 2.06 and 3.6 as described by Liu et al. (2008). 


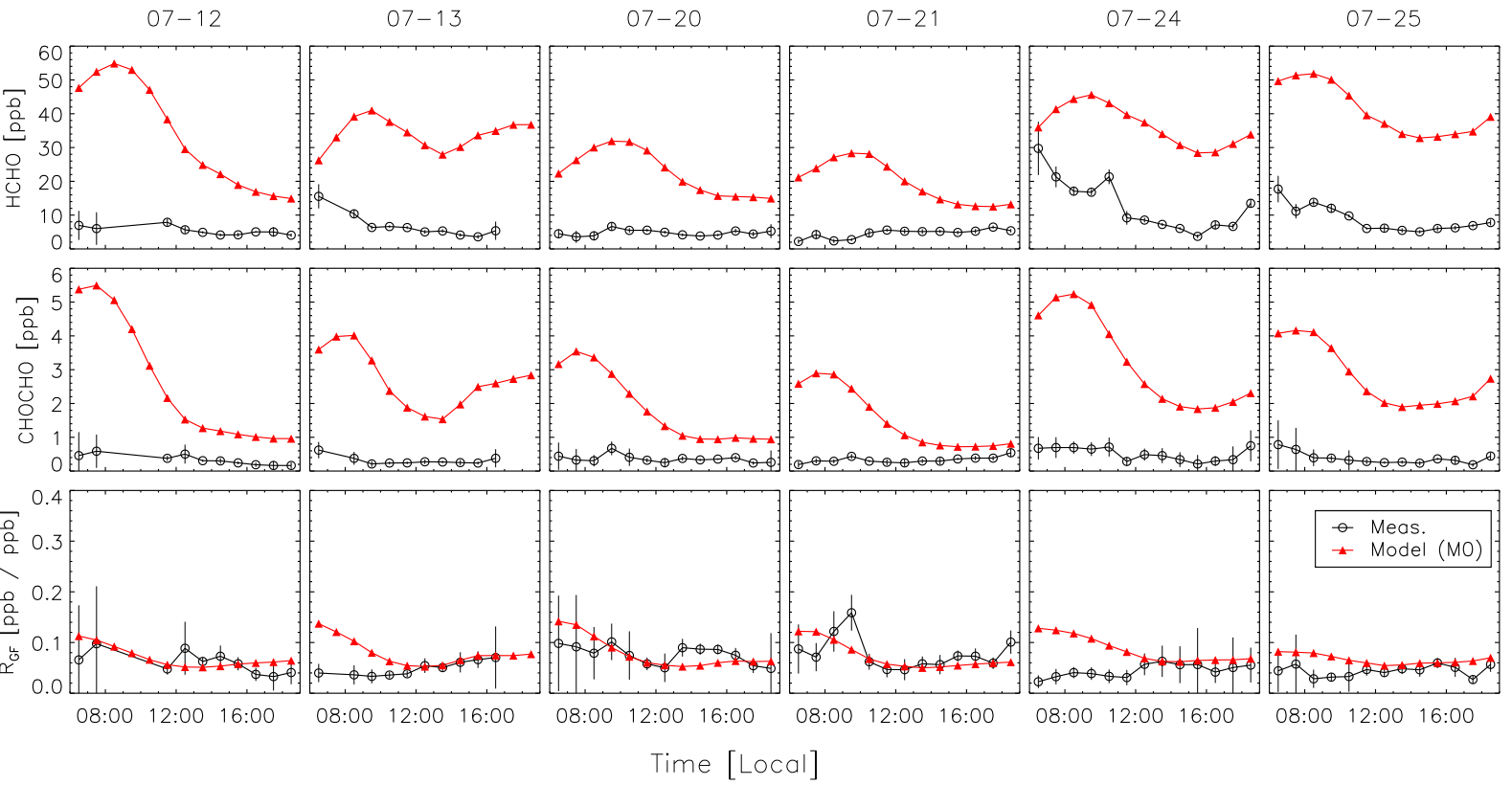

Figure 2. Measured and modeled $\mathrm{HCHO}, \mathrm{CHOCHO}$, and $\mathrm{CHOCHO} / \mathrm{HCHO}$ ratios $\left(R_{\mathrm{GF}}\right)$ for the 6 cloud-free days during the PRIDEPRD2006 campaign. The modeled values are from the model base case (M0). The error bar refers to the $1 \sigma$ statistic error of the measurements.

a decrease of $R_{\mathrm{GF}}$ from morning to noon and stable $R_{\mathrm{GF}}$ values in the afternoon (Fig. 2). Compared to the discrepancy for the $\mathrm{HCHO}$ and $\mathrm{CHOCHO}$ concentrations, the $R_{\mathrm{GF}}$ calculated by the model $(0.075 \pm 0.024)$ is only slightly higher than that by the measurements $(0.059 \pm 0.024)$.

The contribution of different measured NMHCs to the production of $\mathrm{HCHO}$ and $\mathrm{CHOCHO}$ in the model base case is shown in Fig. 3. On average, isoprene oxidation contributes most to the $\mathrm{HCHO}$ production ( $43 \%$ ), followed by the oxidation of alkenes (29\%), aromatics (15\%), and alkanes (13\%). For CHOCHO, half of its production is due to isoprene oxidation, and the other half is dominated by aromatics oxidation. The contributions of alkanes, alkenes, and ethyne to the total CHOCHO production are in total less than $10 \%$. The top-10 precursor NMHCs of $\mathrm{HCHO}$ and $\mathrm{CHOCHO}$ in terms of their production rate are listed in Table 2. Compared to similar studies (e.g., Volkamer et al., 2010; Huisman et al., 2011; Washenfelder et al., 2011; MacDonald et al., 2012; Parrish et al., 2012), anthropogenic and biogenic sources contribute almost equally to the chemical formation of $\mathrm{HCHO}$ and $\mathrm{CHOCHO}$ at the $\mathrm{BG}$ site. However, production of $\mathrm{HCHO}$ and $\mathrm{CHOCHO}$ from anthropogenic precursors is larger than from isoprene before noon; in the afternoon, the contribution of isoprene to $\mathrm{HCHO}$ and $\mathrm{CHOCHO}$ production becomes higher than from anthropogenic NMHCs. This diurnal variation is the result of the change of air mass composition, i.e., from anthropogenically to biogenically dominated. The transition of air mass composition during daytime at the BG site has also been illustrated by Lu et al. (2012) during the analysis of the HOx budget.
Maximum production of $\mathrm{HCHO}$ and $\mathrm{CHOCHO}$ in the model always occurs at around noon, coinciding with the peak of $\mathrm{OH}$ concentrations. We investigated the production of $\mathrm{HCHO}$ and $\mathrm{CHOCHO}$ from the oxidation of NMHCs by different oxidants (i.e., $\mathrm{OH}, \mathrm{O}_{3}$, and $\mathrm{NO}_{3}$ ). In general, $\mathrm{OH}$ initiated oxidation of NMHCs accounts for most of the local production rate of $\mathrm{HCHO}$ and $\mathrm{CHOCHO}(>95 \%)$ throughout the day; ozonolysis and oxidation by $\mathrm{NO}_{3}$ are of minor importance. Compared to $\mathrm{HCHO}$, we did not find any contribution of ozonolysis of alkenes to the $\mathrm{CHOCHO}$ formation. With regard to the oxidation of NMHCs by $\mathrm{NO}_{3}$, its contribution to the $\mathrm{CHOCHO}$ production is larger than to the $\mathrm{HCHO}$ production. The nighttime production of $\mathrm{HCHO}$ and $\mathrm{CHOCHO}$ from $\mathrm{OH}$ initiated oxidation of NMHCs results in the maximum concentration of $\mathrm{HCHO}$ and $\mathrm{CHOCHO}$ occurring in early morning hours. Without existence of $\mathrm{OH}$ during night, the lifetime of HCHO and CHOCHO in the model is determined by dry deposition (i.e., $\tau_{D}=24 \mathrm{~h}$ ), and the production of $\mathrm{HCHO}$ and $\mathrm{CHOCHO}$ from $\mathrm{O}_{3}$ and $\mathrm{NO}_{3}$ reactions is quite small. Therefore, modeled $\mathrm{HCHO}$ and $\mathrm{CHOCHO}$ concentrations during night are determined mainly by the concentrations the day before. In a model run with nighttime $\mathrm{OH}$ concentration fixed to zero, compared to the model base case results, $\mathrm{HCHO}$ and $\mathrm{CHOCHO}$ show much lower concentrations during night and reach their peak concentration at a later time $(\approx 2 \mathrm{~h})$ (Fig. S3).

In the model base case, the destruction of $\mathrm{HCHO}$ and $\mathrm{CHOCHO}$ can be expressed as the sum of first order reaction rates of reaction with $\mathrm{OH}$, photolysis, and dry deposition, i.e., $k_{d}^{\mathrm{HCHO}}$ and $k_{d}^{\mathrm{CHOCHO}}$. It is found that reaction with 
Table 2. Top-10 precursor NMHCs of HCHO and CHOCHO for the 6 cloud-free days during the PRIDE-PRD2006 campaign.

\begin{tabular}{lcllcl}
\hline NMHCs & $P_{\text {HCHO }} \mathrm{ppbh}^{-1}$ & $\%$ & NMHCs & $P_{\text {CHOCHO }} \mathrm{ppb} \mathrm{h}^{-1}$ & $\%$ \\
\hline Isoprene & 3.85 & 43.2 & Isoprene & 0.37 & 51.5 \\
Propene & 0.97 & 12.8 & Toluene & 0.17 & 22.0 \\
Ethene & 0.67 & 8.2 & Ethylbenzene & 0.04 & 5.2 \\
Stryrene & 0.24 & 6.1 & m-Xylene & 0.04 & 5.1 \\
Methane & 0.30 & 4.2 & Ethene & 0.03 & 4.2 \\
m-Xylene & 0.33 & 3.2 & Benzene & 0.03 & 4.0 \\
1-Butene & 0.17 & 2.5 & o-Xylene & 0.02 & 2.8 \\
trans-2-Butene & 0.18 & 2.2 & Ethyne & 0.02 & 2.4 \\
Toluene & 0.21 & 1.9 & 1,2,4-Trimethylbenzene & 0.01 & 1.3 \\
cis-2-Butene & 0.15 & 1.7 & o-Ehtylbenzene & 0.004 & 0.5 \\
\hline
\end{tabular}

Table 3. Relative changes of $\mathrm{HCHO}$ and $\mathrm{CHOCHO}$ mixing ratio and $R_{\mathrm{GF}}$ under different model simulations (Table 1) for the PRIDE-PRD2006 campaign. When the model scenario is changing from $\mathrm{M}_{\mathrm{i}}$ to $\mathrm{M}_{j}(i, j \in[0,4])$, the relative change in percentage is calculated as $\%=100 \times\left(M_{j}-M_{i}\right) / M_{i}$.

\begin{tabular}{llrrr}
\hline Model & Time period & \multicolumn{3}{c}{ Relative change in $\%$} \\
& & HCHO & CHOCHO & $R_{\mathrm{GF}}$ \\
\hline M0 $\rightarrow$ M1 & $06: 00-18: 00$ & -49 & -37 & 22 \\
& $06: 00-10: 00$ & -41 & -22 & 31 \\
& $10: 00-18: 00$ & -53 & -44 & 18 \\
M1 $\rightarrow$ M2 & $06: 00-18: 00$ & -16 & -7 & 13 \\
& $06: 00-10: 00$ & -34 & -16 & 30 \\
& $10: 00-18: 00$ & -7 & -3 & 4 \\
M2 $\rightarrow$ M3 & $06: 00-18: 00$ & -25 & -30 & -8 \\
& $06: 00-10: 00$ & -36 & -40 & -7 \\
& $10: 00-18: 00$ & -19 & -26 & -9 \\
M3 $\rightarrow$ M4 & $06: 00-18: 00$ & -49 & -45 & 4 \\
& $06: 00-10: 00$ & -66 & -71 & -14 \\
& $10: 00-18: 00$ & -40 & -32 & 13 \\
M0 $\rightarrow$ M4 & $06: 00-18: 00$ & -84 & -79 & 30 \\
& $06: 00-10: 00$ & -92 & -89 & 38 \\
& $10: 00-18: 00$ & -80 & -74 & 26 \\
\hline
\end{tabular}

$\mathrm{OH}$ and photolysis are responsible for $90 \%$ of the $\mathrm{HCHO}$ and CHOCHO removal during daytime. During night, $\mathrm{HCHO}$ and $\mathrm{CHOCHO}$ are removed mainly by dry deposition $(60 \%)$; the observation of nighttime $\mathrm{OH}$ with concentrations of around $10^{6} \mathrm{~cm}^{-3}$ accounts for the rest. The lifetime of $\mathrm{HCHO}$ (reciprocal of $k_{d}^{\mathrm{HCHO}}$ ) is more than $10 \mathrm{~h}$ during night and decreases to around $1.3 \mathrm{~h}$ at noon. $\mathrm{CHOCHO}$ has a similar lifetime as $\mathrm{HCHO}$ during the campaign.

\section{Discussion}

\subsection{Reconciliation between the modeled and the measured HCHO and CHOCHO}

Compared to the model base case results, our measurements at the $\mathrm{BG}$ site show much lower concentrations of $\mathrm{HCHO}$ and $\mathrm{CHOCHO}$ which can not be explained by the uncertainties of model and measurements. Moreover, observed concentrations in the afternoon hours do not separate into different groups. To identify the explanation for these discrepancies, we performed a number of sensitivity model runs (Tables 1 and S2). Given that direct emissions of HCHO and $\mathrm{CHOCHO}$ are not considered in the model, periods which are under the influence of local emissions (i.e., early morning of 13, 24, and 25 July) are excluded from the analysis in this section.

The simulated $\mathrm{HCHO}$ and $\mathrm{CHOCHO}$ concentrations in the model are determined by their production and destruction processes. The employed box model could inherently overestimate the yield of $\mathrm{HCHO}$ and $\mathrm{CHOCHO}$ in the oxidation of different NMHCs. In the model base case, isoprene, alkenes and aromatics are the major precursors of $\mathrm{HCHO}$ and CHOCHO (Fig. 3). Firstly, when strong emission sources of these NMHCs exist in the nearby area, the model might not be in steady state resulting in an overestimation of secondary products. Secondly, $\mathrm{HCHO}$ and $\mathrm{CHOCHO}$ concentrations derived from MAX-DOAS measurements represent the average value over a certain horizontal and vertical space. During the 6 cloud-free days, as estimated from the MAX-DOAS measured boundary layer height (BLH) and the visibility inside the boundary layer, the horizontal and vertical extension of the observation volume were both within $\approx 2 \mathrm{~km}$ (Li et al., 2010). If the air mass in this volume was not well mixed, different $\mathrm{HCHO}$ and $\mathrm{CHOCHO}$ production rates compared to the rates calculated from the locally measured $\mathrm{OH}$, NMHCs, etc. would be the consequence. Since $\mathrm{HCHO}$ and $\mathrm{CHOCHO}$ are mainly coming from the reaction of $\mathrm{OH}$ with $\mathrm{NMHCs}$, the above effects can be tested through the sensitivity of the 


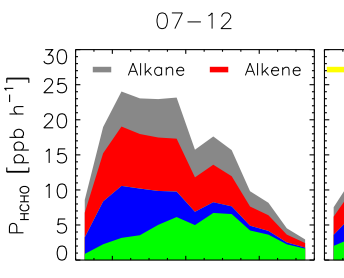

$07-13$
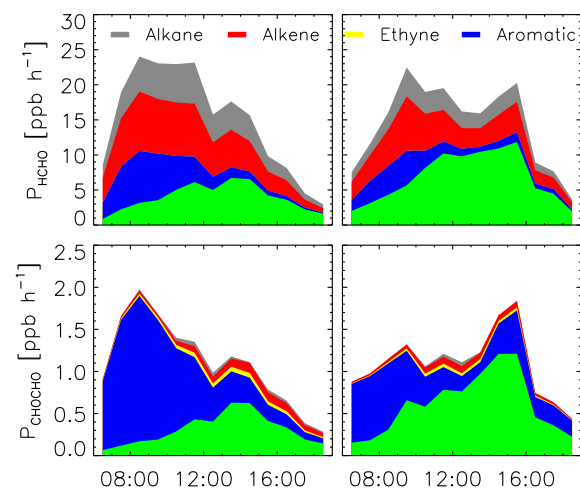

$08.00 \quad 12: 00 \quad 16: 00$

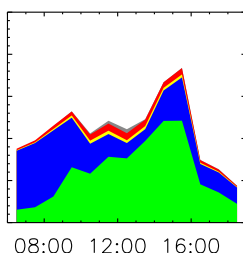

08:00 12:00 16:00
$07-20$
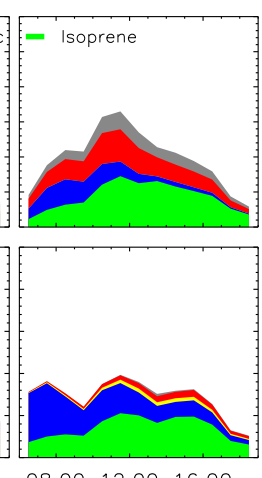

08:00 12:00 16:00
$07-21$
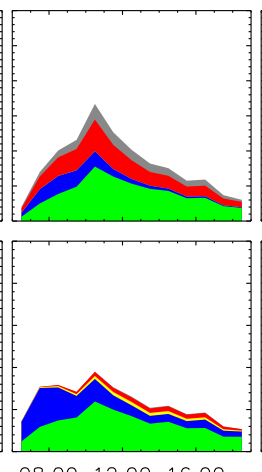

08:00 12:00 16:00
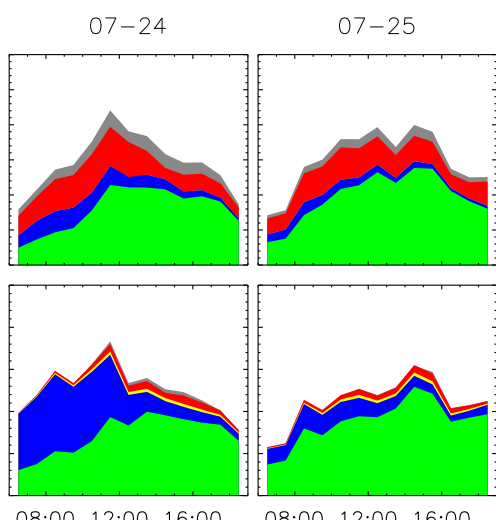

08:00 12:00 16:00

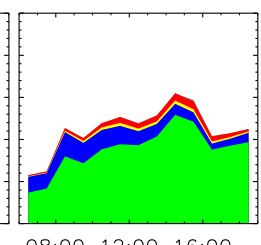

Time [Local]

Figure 3. Production of HCHO and CHOCHO from different NMHCs precursors in the model base case (M0) for the 6 cloud-free days during the PRIDE-PRD2006 campaign.

modeled HCHO and CHOCHO on both (1) different $\tau_{D}$ values and (2) different $\mathrm{OH}$ and NMHC concentrations.

The parameter $\tau_{D}$ can be used as a scale of the generic removal of species included in the model. The shorter the $\tau_{D}$, the faster the removal, resulting in less reaction time $\Delta \mathrm{t}$ (i.e., similar to the photochemical age as used by Fried et al. (2011)) and less oxidation products of primary emitted NMHCs. As described by Lou et al. (2010), oxidation product of the measured NMHCs account for more than $50 \%$ of the measured total $\mathrm{OH}$ reactivity $\left(k_{\mathrm{OH}}\right)$ at the $\mathrm{BG}$ site. Therefore, once $\tau_{D}$ deviates from the real value, modeled $k_{\mathrm{OH}}$ will become different than measured $k_{\mathrm{OH}}$. While $\tau_{D}=24 \mathrm{~h}$, good agreement between modeled and measured $k_{\mathrm{OH}}$ is found in most periods during the campaign. However, on 13, 24, and 25 July when strong isoprene emission existed at the north of the BG site, the value of $\tau_{D}$ during daytime needs to be reduced to $3 \mathrm{~h}$ to let the modeled $k_{\mathrm{OH}}$ match the measured $k_{\mathrm{OH}}$ (Fig. S4), indicating the shorter photochemical age of the measured air mass in these than in the other time periods. It is most likely that the air mass with freshly emitted isoprene was not photochemically degraded when it was detected. Decrease of $\tau_{D}$ from $24 \mathrm{~h}$ to $3 \mathrm{~h}$ results in an average decrease of modeled daytime (06:00-18:00) HCHO and $\mathrm{CHOCHO}$ concentrations by $31 \%$ of the values in the model base case (Fig. S4).

Decrease of $\mathrm{OH}$ concentration by $20 \%$ can result in a maximum decrease of modeled $\mathrm{HCHO}$ and $\mathrm{CHOCHO}$ concentration by $16 \%$ and $20 \%$, respectively. The reconciliation between modeled and measured $\mathrm{HCHO}$ (CHOCHO) concentration would require $\mathrm{OH}$ concentration to be decreased to $<30 \%$ of the measured value (Fig. S3). Similar sensitivity results are found for the NMHC concentrations (Fig. S5). Within $\approx 2 \mathrm{~km}$ along the MAX-DOAS viewing direction, the land is covered homogeneously by trees. It is unlikely that $\mathrm{OH}$ or NMHC concentrations differ by a factor of 2-3 from the local measurements. However, it is possible that some short-lived NMHCs have strong vertical gradients due to vertical mixing. At around noon, the typical mixing time for a species in a well developed convective boundary layer is about $15 \mathrm{~min}$ (c.f. Stull, 1988). Given the observed noontime $\mathrm{OH}$ concentration of $1.5 \times 10^{7} \mathrm{~cm}^{-3}$, this mixing time is longer than the lifetime of isoprene $(\approx 10 \mathrm{~min})$ but is much shorter than the lifetime of aromatics and other alkenes at the BG site. Therefore, it has to be expected that isoprene emitted at ground level would not be well-mixed in the boundary layer within its lifetime. Assuming a vertical exponential decay of the isoprene concentration in the boundary layer and using the measured noontime BLH of around $2 \mathrm{~km}$, the effective average isoprene concentration in the boundary layer is estimated to be only $52 \%$ of the measured value at ground (i.e., the value used in the model base case). For the time period when convective mixing is strong, i.e., 08:00-16:00, we reduced the isoprene concentration in the model to $52 \%$ of the measured value. Compared to the model base case, this change results in an average decrease of modeled $\mathrm{HCHO}$ and $\mathrm{CHOCHO}$ concentration by $15 \%$ for this time period (Fig. S5). The decrease is larger (up to $35 \%$ ) for days when the BG site was influenced by strong isoprene emissions (i.e., 13, 24, and 25 July).

Together with the formation of $\mathrm{HCHO}$ and $\mathrm{CHOCHO}$, hydroperoxides (e.g., $\mathrm{H}_{2} \mathrm{O}_{2}, \mathrm{CH}_{3} \mathrm{OOH}$ ), and peroxyacyl nitrates (PANs) are produced in the oxidation of NMHCs. So, using these measurement results as additional constraints in the model, the prediction of NMHC oxidation processes can be improved (Kormann et al., 2003). It is found that the model run with measured $\mathrm{H}_{2} \mathrm{O}_{2}$ and $\mathrm{CH}_{3} \mathrm{OOH}$ gives nearly the same $\mathrm{HCHO}$ and $\mathrm{CHOCHO}$ concentrations as in the model base case (Fig. S6). Including measured PANs in the model can only lead to a maximum reduction of modeled HCHO concentration by $30 \%$ (Fig. S7). Modeled HCHO and $\mathrm{CHOCHO}$ seem not to be sensitive to the change of hydroperoxide and PAN abundances. 


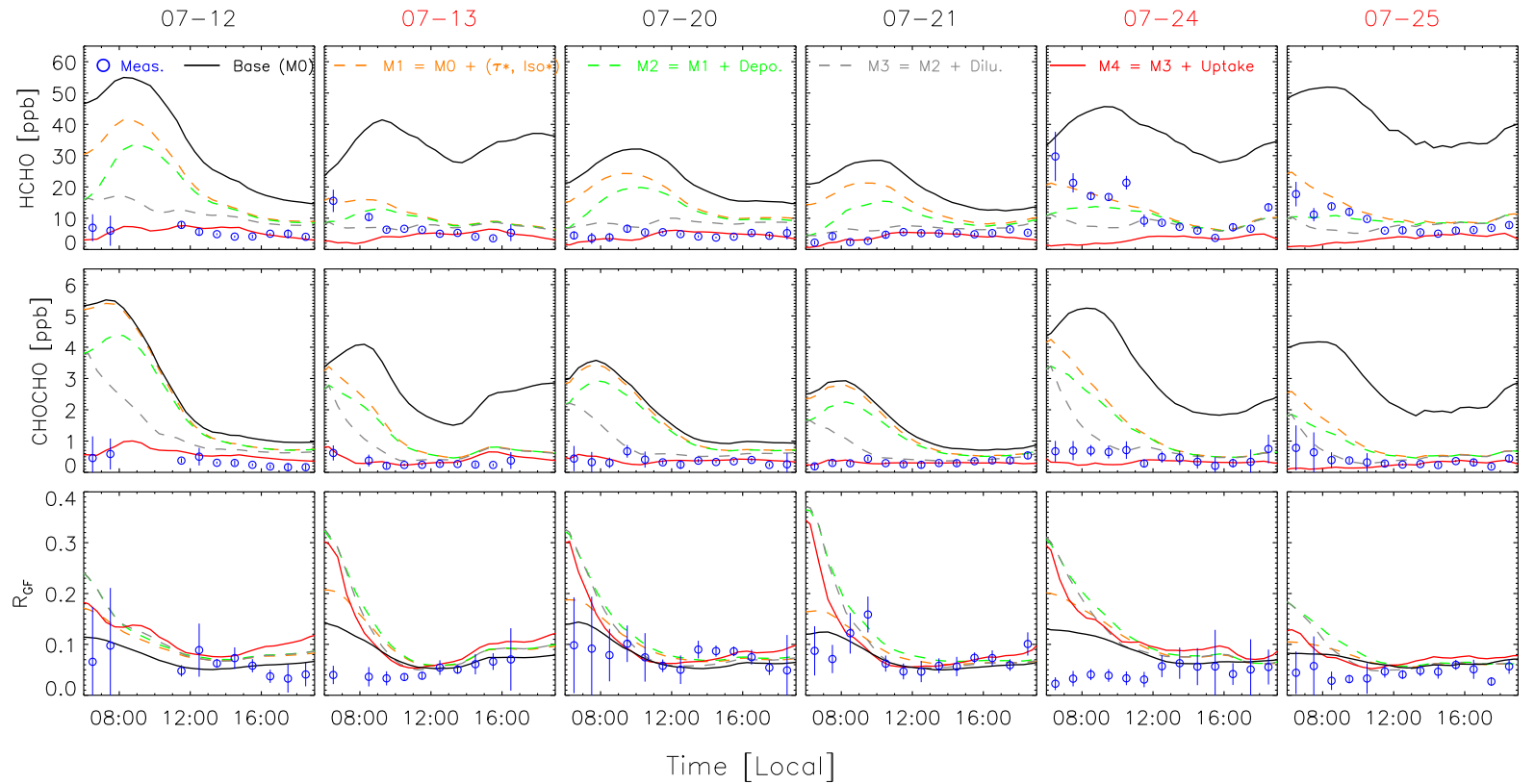

Figure 4. Sensitivity analysis of $\mathrm{HCHO}$ and $\mathrm{CHOCHO}$ simulation for the 6 cloud-free days during the PRIDE-PRD2006 campaign. Dates color coded in red are the days which were influenced by local combustion events. The blue dots are the measured concentrations with error bars indicating the $1 \sigma$ statistic error of the measurements. Symbols with color black, orange, green, gray, and red represent the modeled concentrations by model base case (M0), and M1-M4, respectively. Detailed model settings are described in Table 1 in the text.

By using modified $\tau_{D}$ values and isoprene concentrations in the model, and by including PAN measurements as additional model constraints (model scenario M1), the modeled HCHO (CHOCHO) concentrations during daytime (06:0018:00) decrease by $67 \%(60 \%)$ of the values in the model base case for 13,24 , and 25 July and by $31 \%$ (13\%) for 12 , 20 , and 21 July. Given the uncertainties of model and measurements, the model results agree with the measurements of 13,24 , and 25 July but are still twice as high as the measured values for 12, 20, and 21 July (Fig. 4). Therefore, the uncertainties of the production terms of $\mathrm{HCHO}$ and $\mathrm{CHOCHO}$ in the model can only partly explain the discrepancy between modeled and measured concentrations. As a consequence, $\mathrm{HCHO}$ and $\mathrm{CHOCHO}$ sink terms are most likely underestimated by the model.

Missing $\mathrm{HCHO}$ and $\mathrm{CHOCHO}$ sinks can originate either from the range of the existing $\mathrm{HCHO}$ and $\mathrm{CHOCHO}$ destruction terms in the model (i.e., reaction with $\mathrm{OH}$, photolysis, and dry deposition), or from horizontal advection, vertical dilution, or loss on aerosol surfaces which are not considered in the model.

We showed above that the sensitivity of modeled HCHO and $\mathrm{CHOCHO}$ on the change of $\mathrm{OH}$ concentration can not explain the overestimation of $\mathrm{HCHO}$ and $\mathrm{CHOCHO}$ concentration. Since all days mentioned in this paper showed clearsky conditions, the photolysis frequency measurements were representative enough for the entire MAX-DOAS observation volume. Given that the photolysis frequency measure- ments have an accuracy of $10 \%$, they can only have a minor influence on the overestimation.

Dry deposition of trace gases was included in the model by a constant lifetime $\tau_{D}=24 \mathrm{~h}$, which corresponds to a deposition velocity of $1.6 \mathrm{~cm} \mathrm{~s}^{-1}$ when taking the average measured daytime BLH of $1.4 \mathrm{~km}$. The reported deposition velocities of $\mathrm{HCHO}$ and $\mathrm{CHOCHO}$ are $0.05-1 \mathrm{~cm} \mathrm{~s}^{-1}$ (Stickler et al., 2006) and $0.15-0.3 \mathrm{~cm} \mathrm{~s}^{-1}$ (c.f., Washenfelder et al., 2011), respectively. Though the average loss of HCHO and CHOCHO through dry deposition in the model base case is faster than reported, it does not take the diurnal variation of boundary layer into account. During night, assuming a BLH of $100 \mathrm{~m}$, a deposition velocity of $1 \mathrm{~cm} \mathrm{~s}^{-1}$ results in a lifetime of $2.8 \mathrm{~h}$ which is an order of magnitude shorter than the $\tau_{D}$ of $24 \mathrm{~h}$. This means the loss of $\mathrm{HCHO}$ and $\mathrm{CHOCHO}$ during night should be faster than the model base case predicted. Based on the model scenario M1, we replaced the constant $\tau_{D}$ of $\mathrm{HCHO}(\mathrm{CHOCHO})$ by a time dependent lifetime calculated from the measured BLH (assume nighttime value of $100 \mathrm{~m})$ and a deposition velocity of $1 \mathrm{~cm} \mathrm{~s}^{-1}\left(0.3 \mathrm{~cm} \mathrm{~s}^{-1}\right)$ (model scenario M2). As shown in Fig. 4, for morning hours (06:00-10:00), the calculated HCHO and CHOCHO concentrations by the model scenario M2 decrease by $34 \%$ and $16 \%$ of the values by the model scenario M1, respectively. However, the influence of dry deposition on the modeled $\mathrm{HCHO}$ and $\mathrm{CHOCHO}$ is marginal during the afternoon.

If the air mass detected by MAX-DOAS was inhomogeneously mixed, the $\mathrm{HCHO}$ and $\mathrm{CHOCHO}$ concentrations 
calculated from locally measured $\mathrm{OH}, \mathrm{NMHCs}$, etc. could be different from that at other points. This will result in HCHO and $\mathrm{CHOCHO}$ concentration gradients, and lead to $\mathrm{HCHO}$ and $\mathrm{CHOCHO}$ transport through horizontal advection. During daytime, considering the short lifetime of HCHO and CHOCHO $(\approx 1.5 \mathrm{~h})$, the low wind speed $\left(\approx 2 \mathrm{~m} \mathrm{~s}^{-1}\right)$ at the BG site, and the homogeneous type of land usage along the MAX-DOAS viewing direction, horizontal advection might have only a minor influence on the $\mathrm{HCHO}$ and $\mathrm{CHOCHO}$ simulation.

With regard to the vertical dilution which is caused by the mixing of the shallow (but growing) mixing layer with the nocturnal boundary layer and with the residual layer between sunrise and noon, we can estimate the dilution rate to be constant $\left(k_{\text {dilu }}\right)$ from the decay of the measured black carbon concentrations. During the campaign, the black carbon concentration usually experienced a fast decrease around sunrise (i.e., 06:00-10:00) and showed stable values after 11:00 until sunset. The diurnal variation of the black carbon concentration indicates an efficient vertical dilution in the period of 06:00-10:00, and a well mixed boundary layer since 11:00. In the 6 modeling days, the calculated $k_{\text {dilu }}$ ranges from 0.2 to $0.61 \mathrm{~h}^{-1}$ with an average value of $0.41 \mathrm{~h}^{-1}$. Assuming a constant $k_{\text {dilu }}$ of $0.41 \mathrm{~h}^{-1}$, we applied this removal to all species by vertical dilution for the time period of 06:00-10:00 in the model scenario M2 (i.e., model scenario M3). Compared to the model scenario M2, significant decrease (by $\approx 40 \%$ ) of modeled $\mathrm{HCHO}$ and $\mathrm{CHOCHO}$ concentrations can be identified during morning hours (Fig. 4).

In addition to the modification of production terms of $\mathrm{HCHO}$ and $\mathrm{CHOCHO}$ in the model, including vertical dilution and modified dry deposition (model scenario M3) results in reasonable agreement between modeled and measured $\mathrm{HCHO}$ and $\mathrm{CHOCHO}$ concentrations in most of the time during the 6 cloud-free days (Fig. 4). However, during early morning hours (06:00-09:00), the modeled CHOCHO concentrations are still significantly higher than the measured values. For days without the influence of direct precursor emission in the morning (i.e., 12, 20, and 21 July), the modeled $\mathrm{HCHO}$ concentrations are also higher than the measured values.

Laboratory and field studies indicate that $\mathrm{HCHO}$ and CHOCHO in the gas phase can be lost on aerosols through heterogeneous uptake processes (Volkamer et al., 2007; Wang et al., 2010; Li et al., 2011; Washenfelder et al., 2011; Toda et al., 2014). This uptake process has been shown to be related to the acidity (Jayne et al., 1996; Liggio et al., 2005) or the ionic strength (Kroll et al., 2005) of aerosols. Using an online Aerosol Inorganics Model (AIM, Model II) (http: //www.aim.env.uea.ac.uk/aim/model2/model2a.php) and the method described by Zhang et al. (2007), we estimated $\mathrm{H}^{+}$ activity $a_{\mathrm{H}^{+}}$and ionic strength within the aqueous particle phase from aerosol mass spectrometry (AMS) measurements of $\mathrm{NH}_{4}^{+}, \mathrm{SO}_{4}^{2-}, \mathrm{NO}_{3}^{-}$, and $\mathrm{Cl}^{-}$in PM1. During the daytime of the 6 cloud-free days, the average value of the cal- culated $a_{\mathrm{H}^{+}}$was $1.47 \times 10^{-2} \mathrm{~mol} \mathrm{~L}^{-1}$ (corresponding to a $\mathrm{pH}$ value of 1.8), indicating high aerosol acidity at the BG site. Given the high aerosol concentrations in the early morning hours (Fig. 1), we investigated the sensitivity of modeled $\mathrm{HCHO}$ and $\mathrm{CHOCHO}$ concentrations on heterogeneous uptake processes (i.e., model scenario M4). Using an uptake coefficient of $10^{-3}$ as indicated by laboratory and field studies (Jayne et al., 1996; Liggio et al., 2005; Volkamer et al., 2007), the calculated CHOCHO concentration by the model scenario M4 decrease significantly (by $\approx 70 \%$ ) from that by the model scenario M3 for the early morning hours. In the afternoon, due to decreased aerosol concentration, the influence of the uptake by aerosols on the modeled CHOCHO concentrations becomes small. Compared to the model scenario M3, the model scenario M4 provides better agreement between modeled and measured $\mathrm{HCHO}$ and $\mathrm{CHOCHO}$ concentrations (Fig. 4). Under tropospheric conditions, while the uptake coefficient of $10^{-3}$ can be realistic for $\mathrm{CHOCHO}$, there remains a large uncertainty for HCHO. The value of $10^{-3}$ used in the model scenario M4 for HCHO is estimated from laboratory studies representing typical conditions in the upper troposphere or in the stratosphere (i.e., low temperature and high aerosol acidity) (Jayne et al., 1996). During experiments performed under tropospheric conditions by Kroll et al. (2005), no uptake of HCHO by aerosols was observed. However, some laboratory (Sassine et al., 2010; Li et al., 2011) and field (Wang et al., 2010; Toda et al., 2014) studies identified loss of $\mathrm{HCHO}$ on tropospheric aerosols under certain conditions. Therefore, it is possible that the use of $10^{-3}$ as the $\mathrm{HCHO}$ uptake coefficient could not well represent the condition at the BG site.

Table 3 summarized the relative changes of modeled $\mathrm{HCHO}$ and $\mathrm{CHOCHO}$ concentrations by adding additional processes to the model base case (i.e., model scenarios M1M4). By including additional production and destruction terms (i.e., model scenario M4), the modeled $\mathrm{HCHO}$ and CHOCHO concentrations during daytime (06:00-18:00) decrease by $\approx 80 \%$ of the values predicted by the model base case. On average, the production terms (i.e., deviation from steady-state, vertical transport of isoprene) and the uptake by aerosols have the largest effect $(\approx 50 \%)$ on the concentration decrease, followed by vertical dilution $(\approx 30 \%)$ and deposition $(\approx 15 \%)$. Increased influence of vertical dilution and deposition on the concentration decrease can be found for morning hours.

\subsection{Influences on the $\mathrm{CHOCHO}$ to $\mathrm{HCHO}$ ratio}

As illustrated by Vrekoussis et al. (2010) and DiGangi et al. (2012), the CHOCHO to $\mathrm{HCHO}$ ratio $\left(R_{\mathrm{GF}}\right)$ can be used as an indicator of anthropogenic or biogenic impact on photochemistry. When HCHO and CHOCHO are entirely photochemically formed, $R_{\mathrm{GF}}$ is determined by the relative strength of production and destruction of $\mathrm{HCHO}$ and CHOCHO. When the system is in steady-state, $R_{\mathrm{GF}}$ can be 


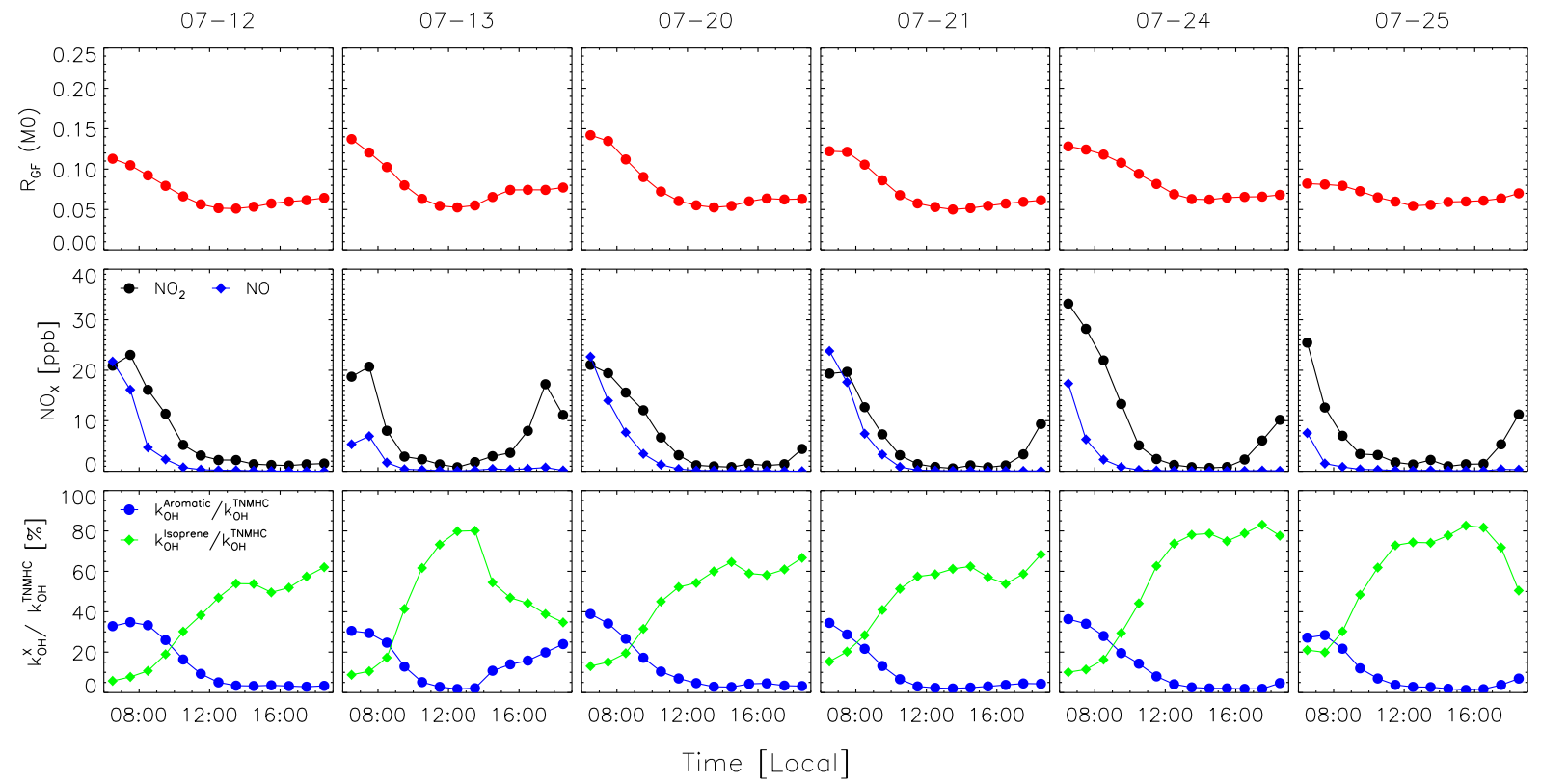

Figure 5. Time series of modeled $R_{\mathrm{GF}}$ (by the model base case), measured $\mathrm{NO}$ and $\mathrm{NO}_{2}$ concentrations and NMHC compositions for the 6 cloud-free days during the PRIDE-PRD2006 campaign. The NMHC composition is expressed as the fraction of OH reactivity of a certain type of NMHC to that of the total NMHC.

expressed as

$R_{\mathrm{GF}}=\frac{[\mathrm{CHOCHO}]}{[\mathrm{HCHO}]}=\frac{P_{\mathrm{CHOCHO}}}{P_{\mathrm{HCHO}}} \cdot \frac{k_{\mathrm{d}}^{\mathrm{HCHO}}}{k_{\mathrm{d}}^{\mathrm{CHOCHO}}}$.

Given a certain $\mathrm{OH}$ concentration, photolysis frequencies, and deposition rate, $k_{d}^{\mathrm{HCHO}} / k_{d}^{\mathrm{CHOCHO}}$ is well defined, and $R_{\mathrm{GF}}$ depends on $P_{\mathrm{CHOCHO}} / P_{\mathrm{HCHO}} \cdot P_{\mathrm{CHOCHO}} / P_{\mathrm{HCHO}}$ is largely influenced by the NMHC composition of the investigated air mass.

In the 6 cloud-free days during the PRIDE-PRD2006 campaign, the average value of measured and modeled (by the model base case) $R_{\mathrm{GF}}$ is $0.059 \pm 0.024$ and $0.075 \pm 0.035$, respectively. In addition to photochemical processes, direct emissions also contribute to ambient HCHO concentrations (Garcia et al., 2006), which would lead to a decease of $R_{\mathrm{GF}}$. Due to the lack of information on the primary HCHO sources for areas around the BG site, $\mathrm{HCHO}$ emission were not included in our model. However, in the early morning of 13 , 24 , and 25 July when combustion events were prevailing in the surrounding areas of the $\mathrm{BG}$ site, we found high $\mathrm{HCHO}$ concentrations and low $R_{\mathrm{GF}}(\approx 0.03)$. So, there is a possibility that some $\mathrm{HCHO}$ primary sources existed in the surrounding area, which causes the discrepancy between modeled and measured $R_{\mathrm{GF}}$.

On the other hand, the model base case can be used to investigate the influence of different chemical processes on the variation of $R_{\mathrm{GF}}$. Given the similarity of the photochemical processes of $\mathrm{HCHO}$ and $\mathrm{CHOCHO}, R_{\mathrm{GF}}$ shows little sensitivity on the total NMHC reactivities $\left(k_{\mathrm{OH}}^{\mathrm{TNMHC}}\right)$. When
$k_{\mathrm{OH}}^{\mathrm{TNMHC}}$ in the model are decreased to half of the measured values, $P_{\mathrm{CHOCHO}}$ and $P_{\mathrm{HCHO}}$ are decreased similarly by $46 \%$ on average. As a result, $R_{\mathrm{GF}}$ remains the same as before. However, $R_{\mathrm{GF}}$ slightly depends on the $\mathrm{OH}$ level. With the decrease of $\mathrm{OH}$ concentration, both $P_{\mathrm{CHOCHO}}, P_{\mathrm{HCHO}}$, $k_{d}^{\mathrm{HCHO}}$, and $k_{d}^{\mathrm{CHOCHO}}$ are found to be decreasing but to different extents. When $\mathrm{OH}$ concentration is decreased to $50 \%$ of the measured values, the decrease of $k_{d}^{\mathrm{HCHO}}$ and $k_{d}^{\mathrm{CHOCHO}}$ are similar (i.e., by $28 \%$ on average), but the decrease of $P_{\mathrm{CHOCHO}}$ (by $55 \%$ on average) is stronger than that of $P_{\mathrm{HCHO}}$ (by $49 \%$ on average). This results in an average decrease of $R_{\mathrm{GF}}$ by $12 \%$. The different dependence between $P_{\mathrm{HCHO}}$ and $P_{\mathrm{CHOCHO}}$ on $\mathrm{OH}$ concentration is caused by the fact that $\mathrm{HCHO}$ and $\mathrm{CHOCHO}$ are produced at different generations of NMHCs oxidation by $\mathrm{OH}$. At the $\mathrm{BG}$ site, oxidation of isoprene and alkenes by $\mathrm{OH}$ is the major process producing $\mathrm{HCHO}$ (Sect. 3.2). During this process, $\mathrm{HCHO}$ is mostly produced as a first generation product and only one $\mathrm{OH}$ radical is consumed when each $\mathrm{HCHO}$ is generated. Therefore, $P_{\mathrm{HCHO}}$ is almost linearly dependent on $\mathrm{OH}$ concentration. However, this situation is different for CHOCHO. Under the conditions at the BG site, we found that $\mathrm{CHOCHO}$ is mostly the third or forth generation product of isoprene and aromatic oxidation by $\mathrm{OH}$. Generating one $\mathrm{CHOCHO}$ molecule needs more than one $\mathrm{OH}$ radical, which leads to a non-linear dependence of $P_{\mathrm{CHOCHO}}$ on $\mathrm{OH}$.

Looking at the time series of modeled $R_{\mathrm{GF}}$ (Fig. 5), high $R_{\mathrm{GF}}$ is usually found in early morning and a sharp decrease of $R_{\mathrm{GF}}$ is identified shortly after sunrise. This 
pattern follows the diurnal variation of $\mathrm{NO}_{\mathrm{x}}$ concentrations and of the contribution of aromatics to the total NMHC reactivities $\left(k_{\mathrm{OH}}^{\text {Aromatics }} / k_{\mathrm{OH}}^{\mathrm{TNMHC}}\right)$, but is opposite to that of the contribution of isoprene to the total NMHC reactivities $\left(k_{\mathrm{OH}}^{\text {Isoprene }} / k_{\mathrm{OH}}^{\mathrm{TNMHC}}\right)$, thereby indicating a positive (negative) impact of the anthropogenic (biogenic) emissions on $R_{\mathrm{GF}}$. A similar phenomenon was observed by DiGangi et al. (2012) at a rural site in the USA. Our model shows that $P_{\mathrm{CHOCHO}} / P_{\mathrm{HCHO}}$ of aromatic compounds (e.g., benzene, toluene, m,p-xylene) are more than 3 times larger than that of isoprene. The $P_{\mathrm{CHOCHO}} / P_{\mathrm{HCHO}}$ of alkanes and alkenes are even smaller than that of isoprene, due to the little contribution of alkanes and alkenes to the $\mathrm{CHOCHO}$ production. Therefore, higher $R_{\mathrm{GF}}$ can be expected when NMHC concentration is dominated by aromatics. Besides the NMHC composition, $\mathrm{NO}_{\mathrm{x}}$ levels can also influence the $R_{\mathrm{GF}}$ since $\mathrm{HCHO}$ and $\mathrm{CHOCHO}$ have different sensitivities to the change of $\mathrm{NO}_{\mathrm{x}}$ concentrations. The $\mathrm{NO}$ level determines the conversion of $\mathrm{RO}_{2}$ to $\mathrm{RO}$ which finally produces $\mathrm{HCHO}$ and CHOCHO. When the NO concentration in the model is increased, a larger concentration increase is found for $\mathrm{HCHO}$ than for CHOCHO leading to a decrease of $R_{\mathrm{GF}}$. This is because the contribution of RO decomposition to the $\mathrm{HCHO}$ formation is larger than to the CHOCHO formation at the BG site. At low-NO, $\mathrm{RO}_{2}+\mathrm{HO}_{2}$ reaction forming hydroperoxides competes with $\mathrm{RO}_{2}+\mathrm{NO}$. Therefore, the sensitivity of $R_{\mathrm{GF}}$ to NO is found to be low and high in high- and lowNO regimes, respectively. In general, an increase of NO concentration by $1 \%$ results in a decrease of $R_{\mathrm{GF}}$ by $0-0.2 \%$. In contrast to $\mathrm{NO}$, an increases of $\mathrm{NO}_{2}$ causes an increase of $R_{\mathrm{GF}}$. This is because, compared to $\mathrm{HCHO}$, the modeled CHOCHO is more sensitive to $\mathrm{NO}_{2}$. Change of $\mathrm{NO}_{2}$ concentrations can have an influence on $\mathrm{OH}$ (via $\mathrm{OH}+\mathrm{NO}_{2}$ ) and $\mathrm{NO}_{3}$ concentrations. Since the $\mathrm{OH}$ concentration in the model is constrained to the measurements, $\mathrm{CHOCHO}$ and $\mathrm{HCHO}$ formation through $\mathrm{OH}$ initiated $\mathrm{NMHC}$ degradations will only be marginally affected when the $\mathrm{NO}_{2}$ concentration is increased / decreased. Since the $\mathrm{NO}_{3}$ reactions have different contribution to the $\mathrm{HCHO}$ and $\mathrm{CHOCHO}$ production (Sect. 3.2), increase of the modeled $\mathrm{NO}_{3}$ concentration as a result of the increase of $\mathrm{NO}_{2}$ can cause the change of $R_{\mathrm{GF}}$. It is found that the change of $R_{\mathrm{GF}}$ ranges from 0 to $0.3 \%$ when the $\mathrm{NO}_{2}$ concentration is changed by $1 \%$; the lower the $\mathrm{NO}_{2}$ concentration, the higher the sensitivity of $R_{\mathrm{GF}}$ to $\mathrm{NO}_{2}$.

Based on above analysis, the modeled diurnal variation of $R_{\mathrm{GF}}$ can be explained by the existence of nighttime $\mathrm{OH}$, by the change of NMHC composition, and by the $\mathrm{NO}_{\mathrm{x}}$ concentration. During night, the existence of significant amounts of $\mathrm{OH}$ radicals made the $\mathrm{OH}+\mathrm{NMHC}$ reactions the major pathway of $\mathrm{HCHO}$ and $\mathrm{CHOCHO}$ formation. The increase of $R_{\mathrm{GF}}$ after sunset is then the result of the increase of $k_{\mathrm{OH}}^{\text {Aromatics }} / k_{\mathrm{OH}}^{\mathrm{TNMHC}}$ and of the $\mathrm{NO}_{2}$ concentration; and the slowing down of the $R_{\mathrm{GF}}$ increase is caused by the occurrence of high NO concentrations later on. Around sunrise, due to the decrease of $k_{\mathrm{OH}}^{\text {Aromatics }} / k_{\mathrm{OH}}^{\mathrm{TNMHC}}$ and of the $\mathrm{NO}_{\mathrm{x}}$ concentration, and the earlier occurrence of $\mathrm{CHOCHO}$ photolysis (compared to $\mathrm{HCHO}$, the absorption cross section of $\mathrm{CHOCHO}$ extends more to the visible wavelength range), the decrease of $P_{\mathrm{CHOCHO}} / P_{\mathrm{HCHO}}$ and of $k_{d}^{\mathrm{HCHO}} / k_{d}^{\mathrm{CHOCHO}}$ lead to the decrease of $R_{\mathrm{GF}}$ in the model. When setting the nighttime $\mathrm{OH}$ concentration to zero, modeled $\mathrm{HCHO}$ and $\mathrm{CHOCHO}$ concentrations during night are then mainly determined by their production in the previous afternoon which are mostly determined through isoprene oxidation (Sect. 3.2). As a result, modeled $R_{\mathrm{GF}}$ during night are as low as those during the previous afternoon when total NMHC reactivity was dominated by isoprene.

In addition to the above factors, additional processes included in the model scenarios M1-M4 also influence the CHOCHO to $\mathrm{HCHO}$ ratio $\left(R_{\mathrm{GF}}\right)$. As shown in Table 3 and Fig. 4, from noon to the afternoon, the modeled $R_{\mathrm{GF}}$ in the model scenario M4 increase by $30 \%$ of the values in the model base case. Larger increase of $R_{\mathrm{GF}}$ can be found during early morning hours, mainly caused by the faster removal of HCHO by dry deposition than that of CHOCHO. Different from other processes, vertical dilution generally causes a small decrease of $R_{\mathrm{GF}}$.

By analyzing satellite measurement results, Vrekoussis et al. (2010) concluded that high $R_{\mathrm{GF}}$ can represent regions strongly influenced by biogenic emissions. However, based on the in situ observations, DiGangi et al. (2012) found that the anthropogenic emissions have positive impact on $R_{\mathrm{GF}}$. Our model study at the BG site indicate that the influence of anthropogenic emissions on $R_{\mathrm{GF}}$ is rather complicated. On the one hand, anthropogenic emissions of aromatics and $\mathrm{NO}_{2}$ can contribute to the increase of $R_{\mathrm{GF}}$. On the other, both emitted NO and $\mathrm{HCHO}$ can lead to a decrease of $R_{\mathrm{GF}}$. For example, compared to the period of 12:00-18:00 on 21 July although the contribution of aromatics to $k_{\mathrm{OH}}^{\mathrm{TNMHC}}$ is lower than on 24 July the lower $\mathrm{NO}$ and higher $\mathrm{NO}_{2}$ concentrations during 24 July caused higher modeled $R_{\mathrm{GF}}$. Moreover, processes like dry deposition and uptake by aerosols also have influence on $R_{\mathrm{GF}}$.

\section{Summary and conclusion}

$\mathrm{HCHO}$ and $\mathrm{CHOCHO}$ are trace gases produced through the oxidation of NMHCs. High vertical column densities of $\mathrm{HCHO}$ and $\mathrm{CHOCHO}$ have been observed by satellite measurements for the Pearl River Delta (PRD) region in southern China, indicating the existence of high photochemical reactivity. However, investigations on the sources and sinks of $\mathrm{HCHO}$ and $\mathrm{CHOCHO}$ in the PRD are rather limited. During the PRIDE-PRD2006 campaign, MAX-DOAS observations of $\mathrm{HCHO}$ and $\mathrm{CHOCHO}$ together with measurements of $\mathrm{HO}_{\mathrm{X}}$ radicals, trace gases, aerosols, and meteorological parameters were performed at the semi-rural site, Back Garden (BG), in the PRD. Using these measurement results and 
a box model, we investigated production and destruction processes of $\mathrm{HCHO}$ and $\mathrm{CHOCHO}$ for 6 cloud-free days during the campaign.

The production of $\mathrm{HCHO}$ and $\mathrm{CHOCHO}$ at the $\mathrm{BG}$ site took place under the combined influence of anthropogenic and biogenic emissions. $\mathrm{OH}$ initiated oxidation of isoprene accounts for nearly half of the $\mathrm{HCHO}$ and $\mathrm{CHOCHO}$ formation, with increased contribution in the afternoon. The anthropogenic source of $\mathrm{HCHO}$ includes the degradation of alkenes $(29 \%)$, aromatics (15\%), and alkanes $(13 \%)$. Besides isoprene, most of the $\mathrm{CHOCHO}$ production is due to the oxidation of aromatics (41\%). While the ozonolysis of alkenes contributes to the formation of $\mathrm{HCHO}$, some $\mathrm{CHOCHO}$ is formed through the oxidation of NMHCs by $\mathrm{NO}_{3}$ radicals. However, compared to the $\mathrm{OH}$ initiated oxidation of NMHCs, ozonolysis of alkenes and $\mathrm{NO}_{3}$ initiated NMHCs degradations are of minor importance in terms of the total $\mathrm{HCHO}$ and $\mathrm{CHOCHO}$ production. The observation of $\mathrm{OH}$ radicals at night results in maximum $\mathrm{HCHO}$ and $\mathrm{CHOCHO}$ concentrations during early morning, which however is different from observations at other places around the world.

Compared to the measurements, the box model overestimates the $\mathrm{HCHO}$ and $\mathrm{CHOCHO}$ concentrations by a factor of 2-5. This discrepancy seems to be caused by a combination of effects each contributing approximately by the same amount, i.e., the lack of knowledge about (1) fresh emissions, (2) fast vertical transport of precursor NMHCs, (3) dry deposition, (4) vertical dilution during the lift of the mixing layer height during early morning hours, and (5) uptake of $\mathrm{HCHO}$ and $\mathrm{CHOCHO}$ by aerosols. Our analysis indicates that, in addition to chemical considerations, physical processes like transport, dilution, and dry deposition have to be well considered for any model predicting $\mathrm{HCHO}$ and $\mathrm{CHOCHO}$ concentrations.

Our model simulations indicate that the $\mathrm{CHOCHO}$ to $\mathrm{HCHO}$ ratio at the $\mathrm{BG}$ site is influenced not only by the NMHC composition but also by the concentration levels of $\mathrm{OH}$ and $\mathrm{NO}_{\mathrm{x}}$. Higher $R_{\mathrm{GF}}$ result from higher aromatic contributions to total NMHCs, from higher $\mathrm{OH}$ and $\mathrm{NO}_{2}$ but lower NO concentrations. Moreover, processes like vertical transport/dilution, dry deposition, and uptake by aerosols can also influence the CHOCHO to HCHO ratio. The complex dependence of $R_{\mathrm{GF}}$ on NMHCs, $\mathrm{OH}, \mathrm{NO}_{\mathrm{x}}$, and other physical / chemical processes makes it difficult to use $R_{\mathrm{GF}}$ as an indicator of anthropogenic or biogenic emissions.

The Supplement related to this article is available online at doi:10.5194/acp-14-12291-2014-supplement.
Acknowledgements. This work was supported by the Strategic Priority Research Program of the Chinese Academy of Sciences (XDB05010500) and the National Natural Science Foundation of China (21190052). The research was also supported by the Collaborative Innovation Center for Regional Environmental Quality.

The service charges for this open access publication have been covered by a Research Centre of the Helmholtz Association.

Edited by: S. C. Liu

\section{References}

Choi, W., Faloona, I. C., Bouvier-Brown, N. C., McKay, M., Goldstein, A. H., Mao, J., Brune, W. H., LaFranchi, B. W., Cohen, R. C., Wolfe, G. M., Thornton, J. A., Sonnenfroh, D. M., and Millet, D. B.: Observations of elevated formaldehyde over a forest canopy suggest missing sources from rapid oxidation of arboreal hydrocarbons, Atmos. Chem. Phys., 10, 8761-8781, doi:10.5194/acp-10-8761-2010, 2010.

DiGangi, J. P., Boyle, E. S., Karl, T., Harley, P., Turnipseed, A., Kim, S., Cantrell, C., Maudlin III, R. L., Zheng, W., Flocke, F., Hall, S. R., Ullmann, K., Nakashima, Y., Paul, J. B., Wolfe, G. M., Desai, A. R., Kajii, Y., Guenther, A., and Keutsch, F. N.: First direct measurements of formaldehyde flux via eddy covariance: implications for missing in-canopy formaldehyde sources, Atmos. Chem. Phys., 11, 10565-10578, doi:10.5194/acp-1110565-2011, 2011.

DiGangi, J. P., Henry, S. B., Kammrath, A., Boyle, E. S., Kaser, L., Schnitzhofer, R., Graus, M., Turnipseed, A., Park, J.-H., Weber, R. J., Hornbrook, R. S., Cantrell, C. A., Maudlin III, R. L., Kim, S., Nakashima, Y., Wolfe, G. M., Kajii, Y., Apel, E., Goldstein, A. H., Guenther, A., Karl, T., Hansel, A., and Keutsch, F. N.: Observations of glyoxal and formaldehyde as metrics for the anthropogenic impact on rural photochemistry, Atmos. Chem. Phys., 12, 9529-9543, doi:10.5194/acp-12-9529-2012, 2012.

Finlayson-Pitts, B. J. and Pitts, J. N.: Chemistry of the Upper and Lower Atmosphere - Theory, Experiments and Applications, Academic Press, San Diego, first edn., 2000.

Fortems-Cheiney, A., Chevallier, F., Pison, I., Bousquet, P., Saunois, M., Szopa, S., Cressot, C., Kurosu, T. P., Chance, K., and Fried, A.: The formaldehyde budget as seen by a global-scale multiconstraint and multi-species inversion system, Atmos. Chem. Phys., 12, 6699-6721, doi:10.5194/acp-12-6699-2012, 2012.

Fried, A., Crawford, J., Olson, J., Walega, J., Potter, W., Wert, B., Jordan, C., Anderson, B., Shetter, R., Lefer, B., Blake, D., Blake, N., Meinardi, S., Heikes, B., O’Sullivan, D., Snow, J., Fuelberg, H., Kiley, C. M., Sandholm, S., Tan, D., Sachse, G., Singh, H., Faloona, I., Harward, C. N., and Carmichael, G. R.: Airborne tunable diode laser measurements of formaldehyde during TRACEP: Distributions and box model comparisons, J. Geophys. Res., 108, 8798, doi:10.1029/2003jd003451, 2003a.

Fried, A., Wang, Y., Cantrell, C., Wert, B., Walega, J., Ridley, B., Atlas, E., Shetter, R., Lefer, B., Coffey, M. T., Hannigan, J., Blake, D., Blake, N., Meinardi, S., Talbot, B., Dibb, J., Scheuer, E., Wingenter, O., Snow, J., Heikes, B., and Ehhalt, D.: Tunable 
diode laser measurements of formaldehyde during the TOPSE 2000 study: Distributions, trends, and model comparisons, J. Geophys. Res., 108, D4, 8365, doi:10.1029/2002jd002208, 2003 b.

Fried, A., Cantrell, C., Olson, J., Crawford, J. H., Weibring, P., Walega, J., Richter, D., Junkermann, W., Volkamer, R., Sinreich, R., Heikes, B. G., O'Sullivan, D., Blake, D. R., Blake, N., Meinardi, S., Apel, E., Weinheimer, A., Knapp, D., Perring, A., Cohen, R. C., Fuelberg, H., Shetter, R. E., Hall, S. R., Ullmann, K., Brune, W. H., Mao, J., Ren, X., Huey, L. G., Singh, H. B., Hair, J. W., Riemer, D., Diskin, G., and Sachse, G.: Detailed comparisons of airborne formaldehyde measurements with box models during the 2006 INTEX-B and MILAGRO campaigns: potential evidence for significant impacts of unmeasured and multigeneration volatile organic carbon compounds, Atmos. Chem. Phys., 11, 11867-11894, doi:10.5194/acp-11-11867-2011, 2011.

Fu, T.-M., Jacob, D. J., Wittrock, F., Burrows, J. P., Vrekoussis, M., and Henze, D. K.: Global budgets of atmospheric glyoxal and methylglyoxal, and implications for formation of secondary organic aerosols, J. Geophys. Res., 113, D15303, doi:10.1029/2007JD009505, 2008.

Garcia, A. R., Volkamer, R., Molina, L. T., Molina, M. J., Samuelson, J., Mellqvist, J., Galle, B., Herndon, S. C., and Kolb, C. E.: Separation of emitted and photochemical formaldehyde in Mexico City using a statistical analysis and a new pair of gas-phase tracers, Atmos. Chem. Phys., 6, 4545-4557, doi:10.5194/acp-64545-2006, 2006.

Hofzumahaus, A., Rohrer, F., Lu, K., Bohn, B., Brauers, T., Chang, C.-C., Fuchs, H., Holland, F., Kita, K., Kondo, Y., Li, X., Lou, S., Shao, M., Zeng, L., Wahner, A., and Zhang, Y.: Amplified Trace Gas Removal in the Troposphere, Science, 324, 17021704, doi:10.1126/science.1164566, 2009.

Hu, W. W., Hu, M., Deng, Z. Q., Xiao, R., Kondo, Y., Takegawa, N., Zhao, Y. J., Guo, S., and Zhang, Y. H.: The characteristics and origins of carbonaceous aerosol at a rural site of PRD in summer of 2006, Atmos. Chem. Phys., 12, 1811-1822, doi:10.5194/acp12-1811-2012, 2012.

Huisman, A. J., Hottle, J. R., Galloway, M. M., DiGangi, J. P., Coens, K. L., Choi, W., Faloona, I. C., Gilman, J. B., Kuster, W. C., de Gouw, J., Bouvier-Brown, N. C., Goldstein, A. H., LaFranchi, B. W., Cohen, R. C., Wolfe, G. M., Thornton, J. A., Docherty, K. S., Farmer, D. K., Cubison, M. J., Jimenez, J. L., Mao, J., Brune, W. H., and Keutsch, F. N.: Photochemical modeling of glyoxal at a rural site: observations and analysis from BEARPEX 2007, Atmos. Chem. Phys., 11, 8883-8897, doi:10.5194/acp-118883-2011, 2011.

Jang, M. and Kamens, R. M.: Atmospheric Secondary Aerosol Formation by Heterogeneous Reactions of Aldehydes in the Presence of a Sulfuric Acid Aerosol Catalyst, Environ. Sci. Technol., 35, 4758-4766, doi:10.1021/es010790s, 2001.

Jayne, J. T., Worsnop, D. R., Kolb, C. E., Swartz, E., and Davidovits, P.: Uptake of Gas-Phase Formaldehyde by Aqueous Acid Surfaces, J. Phys. Chem., 100, 8015-8022, doi:10.1021/jp953196b, 1996.

Kormann, R., Fischer, H., de Reus, M., Lawrence, M., Brühl, C., von Kuhlmann, R., Holzinger, R., Williams, J., Lelieveld, J., Warneke, C., de Gouw, J., Heland, J., Ziereis, H., and Schlager, H.: Formaldehyde over the eastern Mediterranean during MINOS: Comparison of airborne in-situ measurements with 3D-model results, Atmos. Chem. Phys., 3, 851-861, doi:10.5194/acp-3-851-2003, 2003.

Kroll, J. H., Ng, N. L., Murphy, S. M., Varutbangkul, V., Flagan, R. C., and Seinfeld, J. H.: Chamber studies of secondary organic aerosol growth by reactive uptake of simple carbonyl compounds, J. Geophys. Res., 110, D23 207, doi:10.1029/2005jd006004, 2005.

Lee, M., Heikes, B. G., Jacob, D. J., Sachse, G., and Anderson, B.: Hydrogen peroxide, organic hydroperoxide, and formaldehyde as primary pollutants from biomass burning, J. Geophys. Res., 102, 1301-1309, doi:10.1029/96jd01709, 1997.

Li, X., Brauers, T., Shao, M., Garland, R. M., Wagner, T., Deutschmann, T., and Wahner, A.: MAX-DOAS measurements in southern China: retrieval of aerosol extinctions and validation using ground-based in-situ data, Atmos. Chem. Phys., 10, 20792089, doi:10.5194/acp-10-2079-2010, 2010.

Li, X., Brauers, T., Häseler, R., Bohn, B., Fuchs, H., Hofzumahaus, A., Holland, F., Lou, S., Lu, K. D., Rohrer, F., Hu, M., Zeng, L. M., Zhang, Y. H., Garland, R. M., Su, H., Nowak, A., Wiedensohler, A., Takegawa, N., Shao, M., and Wahner, A.: Exploring the atmospheric chemistry of nitrous acid (HONO) at a rural site in Southern China, Atmos. Chem. Phys., 12, 1497-1513, doi:10.5194/acp-12-1497-2012, 2012.

Li, X., Brauers, T., Hofzumahaus, A., Lu, K., Li, Y. P., Shao, M., Wagner, T., and Wahner, A.: MAX-DOAS measurements of $\mathrm{NO} 2, \mathrm{HCHO}$ and $\mathrm{CHOCHO}$ at a rural site in Southern China, Atmos. Chem. Phys., 13, 2133-2151, doi:10.5194/acp-13-21332013, 2013.

Li, Z., Schwier, A. N., Sareen, N., and McNeill, V. F.: Reactive processing of formaldehyde and acetaldehyde in aqueous aerosol mimics: surface tension depression and secondary organic products, Atmos. Chem. Phys., 11, 11 617-11 629, doi:10.5194/acp11-11617-2011, 2011.

Liggio, J., Li, S.-M., and McLaren, R.: Reactive uptake of glyoxal by particulate matter, J. Geophys. Res., 110, D10304, doi:10.1029/2004jd005113, 2005.

Liu, X., Cheng, Y., Zhang, Y., Jung, J., Sugimoto, N., Chang, S.Y., Kim, Y. J., Fan, S., and Zeng, L.: Influences of relative humidity and particle chemical composition on aerosol scattering properties during the 2006 PRD campaign, Atmos. Environ., 42, 1525-1536, doi:10.1016/j.atmosenv.2007.10.077, 2008.

Liu, Z., Wang, Y., Vrekoussis, M., Richter, A., Wittrock, F., Burrows, J. P., Shao, M., Chang, C.-C., Liu, S.-C., Wang, H., and Chen, C.: Exploring the missing source of glyoxal (CHOCHO) over China, Geophys. Res. Lett., 39, L10812-, doi:10.1029/2012GL051645, 2012.

Lou, S., Holland, F., Rohrer, F., Lu, K., Bohn, B., Brauers, T., Chang, C. C., Fuchs, H., Häseler, R., Kita, K., Kondo, Y., Li, X., Shao, M., Zeng, L., Wahner, A., Zhang, Y., Wang, W., and Hofzumahaus, A.: Atmospheric $\mathrm{OH}$ reactivities in the Pearl River Delta - China in summer 2006: measurement and model results, Atmos. Chem. Phys., 10, 11243-11260, doi:10.5194/acp-10-11243-2010, 2010.

Lu, K. D., Rohrer, F., Holland, F., Fuchs, H., Bohn, B., Brauers, T., Chang, C. C., Häseler, R., Hu, M., Kita, K., Kondo, Y., Li, X., Lou, S. R., Nehr, S., Shao, M., Zeng, L. M., Wahner, A., Zhang, Y. H., and Hofzumahaus, A.: Observation and modelling of $\mathrm{OH}$ and $\mathrm{HO} 2$ concentrations in the Pearl River Delta 2006: a missing 
$\mathrm{OH}$ source in a VOC rich atmosphere, Atmos. Chem. Phys., 12, 1541-1569, doi:10.5194/acp-12-1541-2012, 2012.

MacDonald, S. M., Oetjen, H., Mahajan, A. S., Whalley, L. K., Edwards, P. M., Heard, D. E., Jones, C. E., and Plane, J. M. C.: DOAS measurements of formaldehyde and glyoxal above a south-east Asian tropical rainforest, Atmos. Chem. Phys., 12, 5949-5962, doi:10.5194/acp-12-5949-2012, 2012.

Myriokefalitakis, S., Vrekoussis, M., Tsigaridis, K., Wittrock, F., Richter, A., Brühl, C., Volkamer, R., Burrows, J. P., and Kanakidou, M.: The influence of natural and anthropogenic secondary sources on the glyoxal global distribution, Atmos. Chem. Phys., 8, 4965-4981, doi:10.5194/acp-8-4965-2008, 2008.

Parrish, D. D., Ryerson, T. B., Mellqvist, J., Johansson, J., Fried, A., Richter, D., Walega, J. G., Washenfelder, R. A., de Gouw, J. A., Peischl, J., Aikin, K. C., McKeen, S. A., Frost, G. J., Fehsenfeld, F. C., and Herndon, S. C.: Primary and secondary sources of formaldehyde in urban atmospheres: Houston Texas region, Atmos. Chem. Phys., 12, 3273-3288, doi:10.5194/acp-12-32732012, 2012.

Sassine, M., Burel, L., D'Anna, B., and George, C.: Kinetics of the tropospheric formaldehyde loss onto mineral dust and urban surfaces, Atmos. Environ., 44, 5468-5475, doi:10.1016/j.atmosenv.2009.07.044, 2010.

Schauer, J. J., Kleeman, M. J., Cass, G. R., and Simoneit, B. R. T.: Measurement of Emissions from Air Pollution Sources. 2. C1 through C30 Organic Compounds from Medium Duty Diesel Trucks, Environ. Sci. Technol., 33, 1578-1587, doi:10.1021/es980081n, 1999.

Schauer, J. J., Kleeman, M. J., Cass, G. R., and Simoneit, B. R. T.: Measurement of Emissions from Air Pollution Sources. 5. C1 through C32 Organic Compounds from GasolinePowered Motor Vehicles, Environ. Sci. Technol., 36, 1169-1180, doi:10.1021/es0108077, 2002.

Stavrakou, T., Müller, J. F., De Smedt, I., Van Roozendael, M., Kanakidou, M., Vrekoussis, M., Wittrock, F., Richter, A., and Burrows, J. P.: The continental source of glyoxal estimated by the synergistic use of spaceborne measurements and inverse modelling, Atmos. Chem. Phys., 9, 8431-8446, doi:10.5194/acp-98431-2009, 2009.

Stickler, A., Fischer, H., Williams, J., de Reus, M., Sander, R., Lawrence, M. G., Crowley, J. N., and Lelieveld, J.: Influence of summertime deep convection on formaldehyde in the middle and upper troposphere over Europe, J. Geophys. Res., 111, D14308, doi:10.1029/2005jd007001, 2006.

Stull, R. B.: An Introduction to Boundary Layer Meteorology, Kluwer Academic Publishers, Dordrecht, The Netherlands, 1988.

Tan, Y., Perri, M. J., Seitzinger, S. P., and Turpin, B. J.: Effects of Precursor Concentration and Acidic Sulfate in Aqueous Glyoxal-OH Radical Oxidation and Implications for Secondary Organic Aerosol, Environ. Sci. Technol., 43, 8105-8112, doi:10.1021/es901742f, 2009.
Tie, X., Brasseur, G., Emmons, L., Horowitz, L., and Kinnison, D.: Effects of aerosols on tropospheric oxidants: A global model study, J. Geophys. Res., 106, 22931-22964, doi:10.1029/2001jd900206, 2001.

Toda, K., Yunoki, S., Yanaga, A., Takeuchi, M., Ohira, S.-I., and Dasgupta, P. K.: Formaldehyde Content of Atmospheric Aerosol, Environ. Sci. Technol., 48, 6636-6643, doi:10.1021/es500590e, 2014.

Volkamer, R., San Martini, F., Molina, L. T., Salcedo, D., Jimenez, J. L., and Molina, M. J.: A missing sink for gas-phase glyoxal in Mexico City: Formation of secondary organic aerosol, Geophys. Res. Lett., 34, L19807, doi:10.1029/2007g1030752, 2007.

Volkamer, R., Sheehy, P., Molina, L. T., and Molina, M. J.: Oxidative capacity of the Mexico City atmosphere - Part 1: A radical source perspective, Atmos. Chem. Phys., 10, 6969-6991, doi:10.5194/acp-10-6969-2010, 2010.

Vrekoussis, M., Wittrock, F., Richter, A., and Burrows, J. P.: GOME-2 observations of oxygenated VOCs: what can we learn from the ratio glyoxal to formaldehyde on a global scale?, Atmos. Chem. Phys., 10, 10145-10160, doi:10.5194/acp-1010145-2010, 2010.

Wagner, V., Schiller, C., and Fischer, H.: Formaldehyde measurements in the marine boundary layer of the Indian Ocean during the 1999 INDOEX cruise of the R/V Ronald H. Brown, J. Geophys. Res., 106, 28529-28538, doi:10.1029/2000jd900825, 2001.

Wang, X., Gao, S., Yang, X., Chen, H., Chen, J., Zhuang, G., Surratt, J. D., Chan, M. N., and Seinfeld, J. H.: Evidence for High Molecular Weight Nitrogen-Containing Organic Salts in Urban Aerosols, Environ. Sci. Technol., 44, 4441-4446, doi:10.1021/es1001117, 2010.

Washenfelder, R. A., Young, C. J., Brown, S. S., Angevine, W. M., Atlas, E. L., Blake, D. R., Bon, D. M., Cubison, M. J., de Gouw, J. A., Dusanter, S., Flynn, J., Gilman, J. B., Graus, M., Griffith, S., Grossberg, N., Hayes, P. L., Jimenez, J. L., Kuster, W. C., Lefer, B. L., Pollack, I. B., Ryerson, T. B., Stark, H., Stevens, P. S., and Trainer, M. K.: The glyoxal budget and its contribution to organic aerosol for Los Angeles, California, during CalNex 2010, J. Geophys. Res., 116, D00V02, doi:10.1029/2011JD016314, 2011.

Wittrock, F., Richter, A., Oetjen, H., Burrows, J. P., Kanakidou, M., Myriokefalitakis, S., Volkamer, R., Beirle, S., Platt, U., and Wagner, T.: Simultaneous global observations of glyoxal and formaldehyde from space, Geophys. Res. Lett., 33, L16804, doi:10.1029/2006g1026310, 2006.

Zhang, Q., Jimenez, J. L., Worsnop, D. R., and Canagaratna, M.: A Case Study of Urban Particle Acidity and Its Influence on Secondary Organic Aerosol, Environ. Sci. Technol., 41, 3213-3219, doi:10.1021/es061812j, 2007.

Zhou, X., Lee, Y.-N., Newman, L., Chen, X., and Mopper, K.: Tropospheric formaldehyde concentration at the Mauna Loa Observatory during the Mauna Loa Observatory Photochemistry Experiment 2, J. Geophys. Res., 101, 14711-14719, doi:10.1029/95jd03226, 1996. 